\title{
Geological and biological diversity of seeps in the Sea of Marmara
}

\author{
Ondréas Hélène ${ }^{1,}{ }^{*}$, Olu Karine ${ }^{2}$, Dupre Stéphanie ${ }^{1}$, Scalabrin Carla ${ }^{1}$, Alix Anne-Sophie ${ }^{1}$, \\ Garrocq C ${ }^{1,3}$, Ruffine Livio ${ }^{1}$
}

\begin{abstract}
1 IFREMER, Department of Physical Resources and Deep-Sea Ecosystems, Marine Geosciences Research Unit, 29280, Plouzané, France

2 IFREMER, Department of Physical Resources and Deep-Sea Ecosystems, Deep-Sea Ecosystems Research Unit, 29280, Plouzané, France

${ }^{3}$ Geosciences Montpellier, CNRS, University of Montpellier, France
\end{abstract}

* Corresponding author : Hélène Ondréas, email address : helene.ondreas@ifremer.fr

\begin{abstract}
:
The Sea of Marmara hosts part of the North Anatolian Fault as an active submarine strike-slip fault. This area has suffered numerous earthquakes and presents a major seismic risk. Although the Sea of Marmara has been studied for many years, the link between geological morphostructures, the nature of fluids and biological communities is still rarely described. During the Marsite cruise (November 2014), dives with Remotely Operated Vehicle (ROV) VICTOR 6000 focused on detailed seafloor explorations of four different areas: the Central and Western highs and the Tekirdağ and Çinarcik basins. Based on $130 \mathrm{~h}$ of in situ videos, high-resolution seafloor mapping of seeps was conducted, emphasizing their significant geological and biological diversity from one seeping site to another, from one basin/high to another. Gas bubbles $(\mathrm{CH} 4, \mathrm{CO} 2)$, shimmering water (brine, marine and fresh water) and oil, escape from the seafloor into the water column with low to strong fluxes. Black patches of reduced sediments, authigenic carbonate crusts and chimneys compose the seep environments with various types of bacterial mats and chemosynthetic fauna. Several venting sites discovered during previous cruises are still active 7-12 years later. The seeps are mostly, but not only, focalized along the Main Marmara Fault (MMF), at the southern border of the Tekirdağ Basin and along the Western High. Fluid emission is also occurring at secondary faults and at their intersection with the MMF. Our study emphasizes the location of seeps at the foot of slopes, gully outlets and crossroads. Sedimentary features, such as mass wastings, stratigraphic discontinuities or canyons, also interact with fluid emissions. The observed fauna is dominated by Bathymodiolinae, Vesicomyidae, Lucinidae-like empty shells and tubiculous worms resembling Ampharetidae polychatea. Most of the symbiont-bearing taxa encountered and previously sampled in the Marmara Sea, are characterized by thiotrophic symbioses. Vesicomyids and Idas sp. mussels are present at gas seeps, but also in areas where crude oil escapes from the seafloor. Moreover, other taxa unusually encountered at cold seeps such as large-sized amphipod and vagile worms were observed in the Çinarcik Basin. Idas-like mussels were observed in the western part of the Sea of Marmara, in the Tekirdağ Basin and possibly on the Western High active seep sites. There, the sampled fluids had high methane content (reaching $65 \mu \mathrm{mol} / \mathrm{l})$ but not as high as on the Central High $(363 \mu \mathrm{mol} / \mathrm{l})$ and Çinarcik Basin $(228 \mu \mathrm{mol} / \mathrm{l})$ where no mussels were observed in the video records. Bottom waters oxygen levels in the Sea of Marmara showed a west to east decreasing gradient (57-8.5 $\mu \mathrm{mol} / \mathrm{l})$. These oxygen conditions, which fall under the limit of Oxygen Minimum Zones $(\mathrm{OMZ}<20 \mu \mathrm{m} / \mathrm{l})$ in the eastern part, may impact benthic fauna
\end{abstract}


and explain the absence of symbiotrophic bivalves at cold seep sites of the Çinarcik Basin, whereas densely aggregated amphipods, likely more tolerant to oxygen stress were observed in the seepage area. Finally, no specific fauna was observed near the CO2-rich seep sites. First observations suggest that seep fauna composition in the Sea of Marmara does not seem to be strongly influenced by the nature (e.g., oil, gas bubbling, brines) of fluid venting through seeps. The seep environments are highly variable and characterized by distinctive geological morphostructures. They sustain typical Mediterranean cold seep fauna, but also unusual communities likely related to the interaction of seeps with hypoxic conditions.

\section{Highlights}

Seeps distribution is strongly related to tectonic and sedimentological features. Settling of fauna seems not connected to nature of fluid escapes. Low levels of seawater oxygen promote the settling of specific fauna species.

Keywords : Sea of Marmara, Cold seeps, Fluids, Seismogenic faults, Chemosynthetic fauna, Methane 
51 Expulsion of fluids (e. g. $\mathrm{CH}_{4}, \mathrm{CO}_{2}$, heavy hydrocarbon gases, brines, liquid hydrocarbons, marine and fresh waters)

52 on submerged continental margins is of widespread occurrence worldwide (Judd and Hovland, 2007; Suess, 2014).

53 These fluids are generated at various depths in the sedimentary column, and may be involved in geochemical and microbial-mediated reactions (e.g., solid precipitations) during their migration. Their upward ascending can result in the formation of different morphologies at the sea bottom, such as mud volcanoes (Milkov et al., 2004), pockmarks (Marcon et al., 2014), carbonate build-ups (Greinert et al., 2001) and brine lakes (Dupré et al., 2014). Thus, the entire sedimentary column as well as the seafloor are both source and sink for a wide variety of chemical components (Suess, 2014). The water column also hosts chemical components which react with those present in the ascending fluids. Methane or organic matter through sulfates release hydrogen sulfide. In marine sediment, sulfate reduction is coupled either with the organic matter oxidation (Meister et al., 2013) or the Anaerobic Oxidation of Methane (Reeburgh, 1976; Hinrichs et al., 1999), or both. Whatever the coupled-oxidation process, the whole redox reaction releases bicarbonate ions that enhances the precipitation of carbonates. These two reactions result in an increase in the alkalinity of pore waters and, as a consequence, lead to precipitation of authigenic carbonates in the near seafloor environment (Ritger et al., 1987; Michaelis et al., 2002). All these reactions commonly induce a shallow sulfate reduction zone resulting in "black patches" on the seafloor which may be colonized by sulfur-oxidizing bacteria 66 (Niemann et al., 2006; Lazar et al., 2011).

67 Several cold seep sites colonized by the symbiotrophic fauna have been described in the eastern Mediterranean Sea, at 68 mud volcanoes along the Mediterranean Ridge, in the Anaximander Mountains south of Turkey (Olu-Le Roy et al., 2004; Ritt et al., 2012a) and later in the Nile Deep Sea Fan associated with various geological structures (Dupré et al., 2007; Bayon et al., 2009; Ritt et al., 2011). Mediterranean cold seep fauna include bivalve families commonly encountered also at other cold seeps: Bathymodiolinae mussels, Vesicomyidae and Lucinidae clams. However, they are usually smaller than their Atlantic counterparts such as the small Idas modioliformis or the vesicomyid Isorropodon perplexum (Olu-Le Roy et al., 2004; Von Cosel and Salas, 2001). The Siboglinidae tubeworm 74 Lamellibrachia anaximandri (Southward et al., 2011) colonize several of these cold seep sites. Among symbiont- 
bearing taxa, only bivalves, including the same or closely related species to those of the Eastern Mediterranean, have been reported from the Sea of Marmara (SoM) (Ritt et al. 2010; 2012b).

The North Anatolian Fault Zone is an active strike-slip fault with a submerged portion crossing the SoM. It has suffered numerous earthquakes and the whole region presents a major seismic risk (Ambraseys, 2002; Ambraseys and Jackson, 2000). However, a whole century without an earthquake along some segments of the SoM (Bohnhoff et al., 2013; Schmittbuhl et al., 2016; Sakic et al., 2016) and the accumulating strain on the Central High segment (Ergintav et al., 2014), within proximity of the city of Istanbul with a population of 15 million, highlight the relevant and urgent objective to study the nature and distribution of seeps in these areas to enhance our understanding of relationships between fluids and earthquakes.

In 2014, using the Remotely Operated Vehicle (ROV) VICTOR 6000, the Marsite cruise (Géli et al., 2014) on the Research Vessel (R/V) Pourquoi pas? focused on detailed seafloor explorations of selected areas in the SoM (Ruffine et al., 2018b). Moreover, samples of sediments, authigenic carbonates, fluids and a few fauna and microbiological 
materials were collected (Çağatay et al., 2018; Ruffine et al, 2018b; Teichert et al., 2018) and analyzed for further insight into the links between fluid migration, fault dynamics and seismic activities in the Marmara Region.

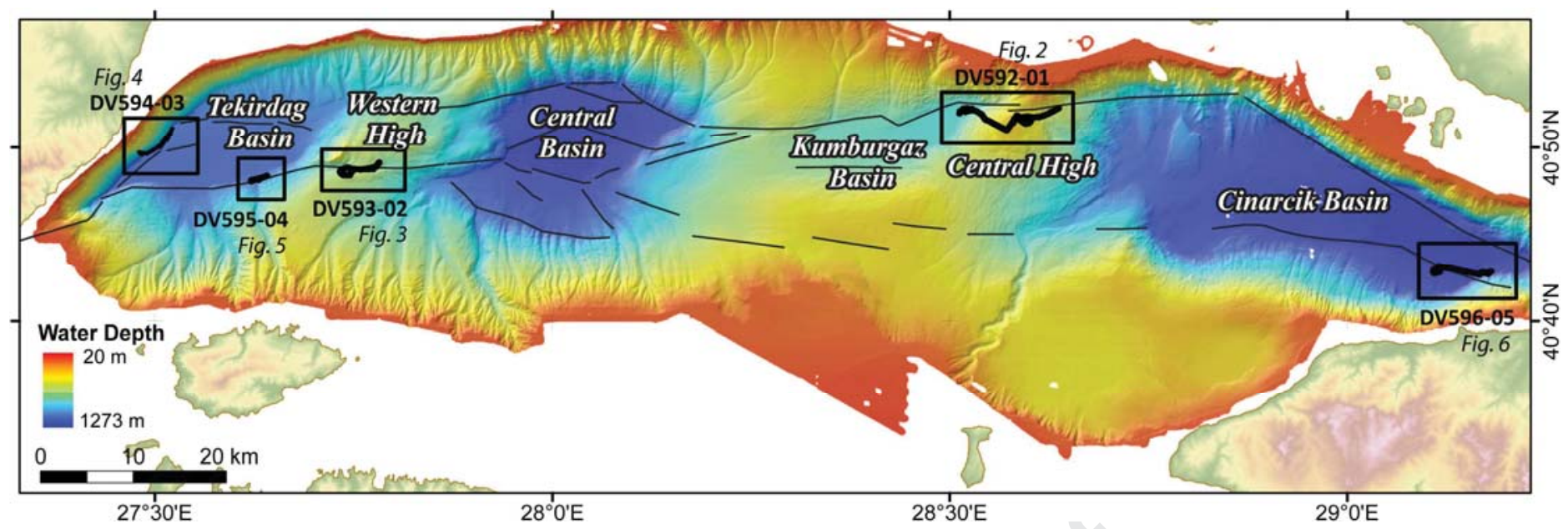

Figure 1: Location map of the Marsite cruise. ROV dives overprint on the bathymetry of the SoM (Rangin et al., 2001),

In this paper, we present the results of the ROV dive explorations carried out in the Tekirdağ and Çinarcik basins and on the Central and Western highs (Figure 1). Video data analysis details the local environment of seeps including the discovery of new ones, providing accurate localization and morphology on the sea bottom. The links between seeps and local morphological structures (Grall et al., 2018a), and associated fauna visible on images are discussed (Table I in supplementary materials).

Our results highlight the wide diversity of the seeps and associated benthic and chemosynthetic ecosystems in the explored zones, at different scales from site to site or basin to high. The following questions are discussed: what are the most significant parameters driving geological and biological diversities and what is the role of tectonic, sedimentary controls and nature of gas and intensity of flux on these diversities?

\section{Geological and biological backgrounds}

The SoM has been studied for many years (Le Pichon et al., 2001; Armijo et al.; 2002 and 2005, Henry et al., 2007a; 2007b; Géli et al., 2008; Ruffine et al., 2018b). Tens of papers have been published, focusing on tectonic processes (Görür and Elbek, 2013), the evolution of the North Anatolian Fault (NAF) (Le Pichon et al., 2001; Imren et al., 2001; Armijo et al., 2002, Şengör et al., 2014), geophysical interpretations of fault systems (Parke et al., 1999; Okay et al., 2000; Imren et al., 2001; Le Pichon et al., 2001), fluid emissions (Dupré et al., 2015), the geological context of seeps (Zitter et al., 2008; Grall et al., 2018a; Ruffine et al., 2018b) and the geochemistry of fluids and gases (Bourry et al., 2009; Ruffine et al., 2012; 2015; 2018a).

The hydrocarbon-bearing Thrace Basin (Görür and Elbek, 2013) possibly extends onto the most northern part of the SoM. It was initiated during the Eocene as a fore-arc basin above a subduction zone and was followed by a collision phase when the Tethyan Ocean closed (Görür and Elbek 2013; Şengör et al., 2005 and 2014). A slide-slip motion initiated during the Late Miocene (Şengör, 1979) induced Riedel and anti-Riedel shear structures, P-shears, post-peak and pre-residual structures. The North Anatolian Fault (NAF) was formed 11 to 13 Ma ago and propagated westwards resulting in the development of the Sea of Marmara during the Late Pliocene to Pleistocene (Şengör et al., 2005; 
2014). The most active part of the northern branch of the NAF is the MMF (Le Pichon et al., 2001) extending eastwest from the Gulf of İzmit to the Ganos Fault. During the last glacial period, the SoM experienced a freshwater lake stage before the initial transgression by the Mediterranean waters at $14.7 \mathrm{kyr}$ BP (Vidal et al., 2010) and complete marine connection at $12.55 \mathrm{kyr}$ BP with increased salinity suitable for eurihaline marine mollusks. (Çağatay et al., 2000 and 2015). The current tectonic regime of the northern branch of the NAF has been described as dominated by single throughgoing purely strike-slip fault (Le Pichon et al., 2001) or by dominant transtensional tectonics with segmented pull-apart fault geometry (Armijo et al., 2002). Although recent studies conclude on a locked Central High segment (Ergintav et al., 2014), the mechanical behaviour of this segment is still open to debate with the two following end members: locked segment (Sakic et al., 2016) versus segment where motion is accommodated by aseismic creep (Ergintav et al., 2014).

Over the entire SoM, the MMF shows well-expressed fault morphology at the seafloor (Armijo et al., 2005), in particular the WNW-trending Northern Çınarcık segment, the Central High segment, the Central Basin-Western High segment, the Central High-South Tekirdağ segment, and the transpressive Ganos segment (Çağatay and Uçarkuş, 2018). Widespread gas emissions in the water column have been discovered and imaged by acoustic data (Géli et al., 2008; Dupré et al., 2015) and confirmed by in situ observations, samples and measurements (Armijo et al., 2005; Henry et al., 2007b; Zitter et al., 2008). Gas bubble and shimmering water escapes (Armijo et al., 2005; Burnard et al., 2012; Géli et al., 2008; Tryon et al., 2010; Zitter et al., 2008), black patches of reduced sediments (Zitter et al., 2008), authigenic carbonate crusts and chimneys (Crémière et al., 2012; Akhoudas et al., 2018; Çağatay et al., 2018; Teichert et al., 2018) and bacterial mats and chemosynthetic fauna (Ritt et al., 2010 and 2012b) characterize the cold seep environments of the SoM. After Armijo et al., (2005) using the ROV Victor to conduct the first in situ explorations, Zitter et al., (2008) presented an extensive study of occurrence of seeps along the MMF and at the edge of the basins, emphasizing the link between fluid escapes, tectonic and sedimentary processes. The sulfate methane transition zone (SMTZ) can be observed a few meters below seafloor in the Sea of Marmara (Halbach et al., 2004; Çağatay et al., 2004; Zitter et al., 2008; Tryon et al., 2010). In the Çinarcik basin, the anaerobic oxidation of methane coupled with sulphate reduction in the SoM has been identified at different depths within the sediment, from 10 to $12 \mathrm{~cm}$ depth below seafloor (Chevalier et al., 2013) to 3 to $4 \mathrm{~m}$ depth (Çağatay et al., 2004). Analysis of the Marsite cruise samples taken along the south-eastern slope of the Çinarcik Basin, show that this transition zone is present in the first $20 \mathrm{~cm}$ below the seafloor (Teichert et al., 2018). In this zone, AOM is the major sink process of methane-derived carbon with the precipitation of authigenic carbonates (Chevalier et al., 2011; Crémière et al., 2012; Çağatay et al., 2018). However, oxidation of hydrocarbons heavier than methane (e.g., crude oil), is also involved in carbonate authigenesis (Chevalier et al., 2011). The authigenic carbonates of the SoM are mainly composed of aragonite, Mg-calcite and minor amounts of dolomite that incorporate also biological fragments (Crémière et al., 2012; Çağatay et al., 2018). Analyses of carbonate concretions from the Marsite push-cores collected within the first $18 \mathrm{~cm}$ of sediment confirmed these results. Total carbonate content ranges between $55 \%$ and $84 \%$ with aragonite dominance, in association with minor proportions of high magnesium calcite (Çağatay et al., 2018; Ruffine et al., 2018b).

Comparison of fluid geochemical results from samples collected during several cruises (2007, 2009 and 2014), has shown that methane is the dominant component of the gases emitted in the SoM (Ruffine et al., 2018b). It is also the major component of hydrates sampled on the mud volcanoes of the Western High (Bourry et al., 2009) where methane 
of thermogenic origin as well as brines of up to twice the seawater salinity (Tryon et al., 2010) are expelled atop the mud volcanoes. The positive $\delta^{13} \mathrm{C}$ values of a few buried carbonate concretions from the Western High ridge reflect the mineralization of heavy $\mathrm{CO}_{2}$, which is interpreted to represent the residual by-product of oil biodegradation in a subsurface petroleum reservoir. This product migrated upwards with the brines (Crémière et al., 2012). On the Central High, methane gas bubbles are also of thermogenic origin. In contrast, in the Çinarcik Basin and on the southern part of the Tekirdağ Basin (e.g., near the Jack chimney; Zitter et al., 2008), pore fluids are dominated by the influence of Lake Marmara brackish water (Tryon et al., 2010), and the emitted gas has a primarily microbial origin (Bourry et al., 2009; Ruffine et al., 2015, 2018a). Regarding the NW border of the Tekirdağ Basin, some seeps are characterized by a high $\mathrm{CO}_{2}$ content, reaching up to 97\%-mol of total gases (site $\mathrm{CO}_{2} \mathrm{~A}$ in Ruffine et al., 2018a) while some others expel thermogenic methane (e.g., Dallas site; Ruffine et al., 2018a).

Only one ecological study has described chemosynthesis-based fauna associated with fluid emissions in the SoM (Ritt et al., 2010). This first exploration revealed some similarities with the Mediterranean cold seeps in the faunal composition presenting the same vesicomyid and lucinid species (Ritt et al., 2010), but a small, still formally undescribed mytilid, but differing morphologically and genetically from Idas modiolaeformis was discovered (Ritt et al., 2012b). The different microhabitats in the Central and Tekirdağ basins, including reduced sediments, bioturbated sediments and carbonate crusts, differ in the symbiont-bearing taxa component and from other macrofauna not relying on chemosynthesis present there. Symbiont-bearing Idas-like mussels colonize carbonate crusts associated with cold seeps in the western slope of both basins (Ritt et al., 2012b). Ampharetidae and Dorvilleidae polychaetes are adapted to sulfide rich and oxygen depleted sediments and were sampled in reduced sediments. However, the vesicomyid Isorropodon perplexum and the lucinid Lucinoma kazani colonize bioturbated sediments with sulphide production occurring at greater depths (Ritt et al., 2010). Chemical gradients (i.e. methane, oxygen and probably sulphides) have been proposed as the most important factors influencing faunal distribution (Ritt et al., 2010).

\section{Material and methods}

Based on previous operations carried out in the SoM for many years (seafloor and water column acoustic surveys, Autonomous Underwater Vehicle mapping, seismic acquisitions, water, sediment and gas sampling), the Marsite cruise used a specific strategy to efficiently sample cold seeps (Ruffine et al., 2018b). The procedure was based on accurate acoustic surveys to identify and localize venting sites, followed by ROV dives (Figure 1). Before the Marsite cruise, the ROV VICTOR dive sites were defined according to the results from previous cruises (Dupré et al., 2015). During the Marsite cruise and before each ROV dive, an acoustic coverage was carried out with the ship-borne multibeam echosounder (RESON 7150, $24 \mathrm{kHz}, 880$ beams) with three main objectives: (1) confirm the presence of gas emissions in the water column, (2) detect and localize new fluid escapes and (3) refine at best the planned dive tracks. The ROV VICTOR dives were dedicated to: i) exploration of seeps and vents on the sea bottom and ii) in situ gas sampling with gas-bubble sampler PEGAZ (Lantéri and Bignon, 2007), followed by composition assessment by primary onboard chemical analyses (Ruffine et al., 2018b). The PEGAZ sampler collects gas bubbles and preserves the sample at in situ pressure. The nature and origin of fluids were subsequently refined based on accurate onshore laboratory studies (Ruffine et al., 2018a; 2018b). Visual seafloor observations were made (Figure 1) along the whole longitudinal gradient of the SoM (two degrees), at water depths varying between 320 and $1250 \mathrm{~m}$ (data available: 
http://video.ifremer.fr/index). The analysis of 130 hours of in situ videos has resulted in high-resolution geological seafloor mapping along the ROV tracks with localization of fluid escapes and seep-related structures. Using the videos, a summary table showing the main seep characteristics per dive/segment is presented as supplementary material. A mosaic imaging the Bulot-Boubouns-Chnikov site (BBC) located NW on Tekirdağ Basin has been produced using parts of video transects (Matisse Software - (C) Ifremer). Five ROV dives were performed, three into the basins and two on the highs, accounting for 56 kilometers of tracks on the sea bottom (see video in supplementary data). Vent flow rates were measured with a custom-made flowmeter at thirty sites. This flowmeter uses visual estimation to evaluate the flow rate by calculating the speed of passage of particles in a graduated cylinder of $50 \mathrm{ml}$. It is calibrated by the fact that the evaluated volume is constant and well defined. The flow rates observed in the in situ video images were compared with the in situ measurements and classified in three different categories: low rate: lower than 300/400 mLn. $\mathrm{min}^{-1}$ (n for normalized to atmospheric pressure), medium rate: between $\sim 300 / 400$ and $8000 \mathrm{mLn} \cdot \mathrm{min}^{-1}$ and strong rate: greater than $8000 \mathrm{mLn} \cdot \mathrm{min}^{-1}$ (Table I in supplementary material). Then, with these classes we were able to estimate flow rates at seeps where no in situ measurements were performed. In addition, near-seafloor exploration has led to document the fauna visually observed in video records (see video in supplementary data) for the different investigated areas (Plate I). The fact that fauna was observed and not sampled limits the identifications to the family level at best. Moreover, above the seafloor were observed empty Lucinid shells but living specimens of this burying bivalve could not therefore be assessed. 


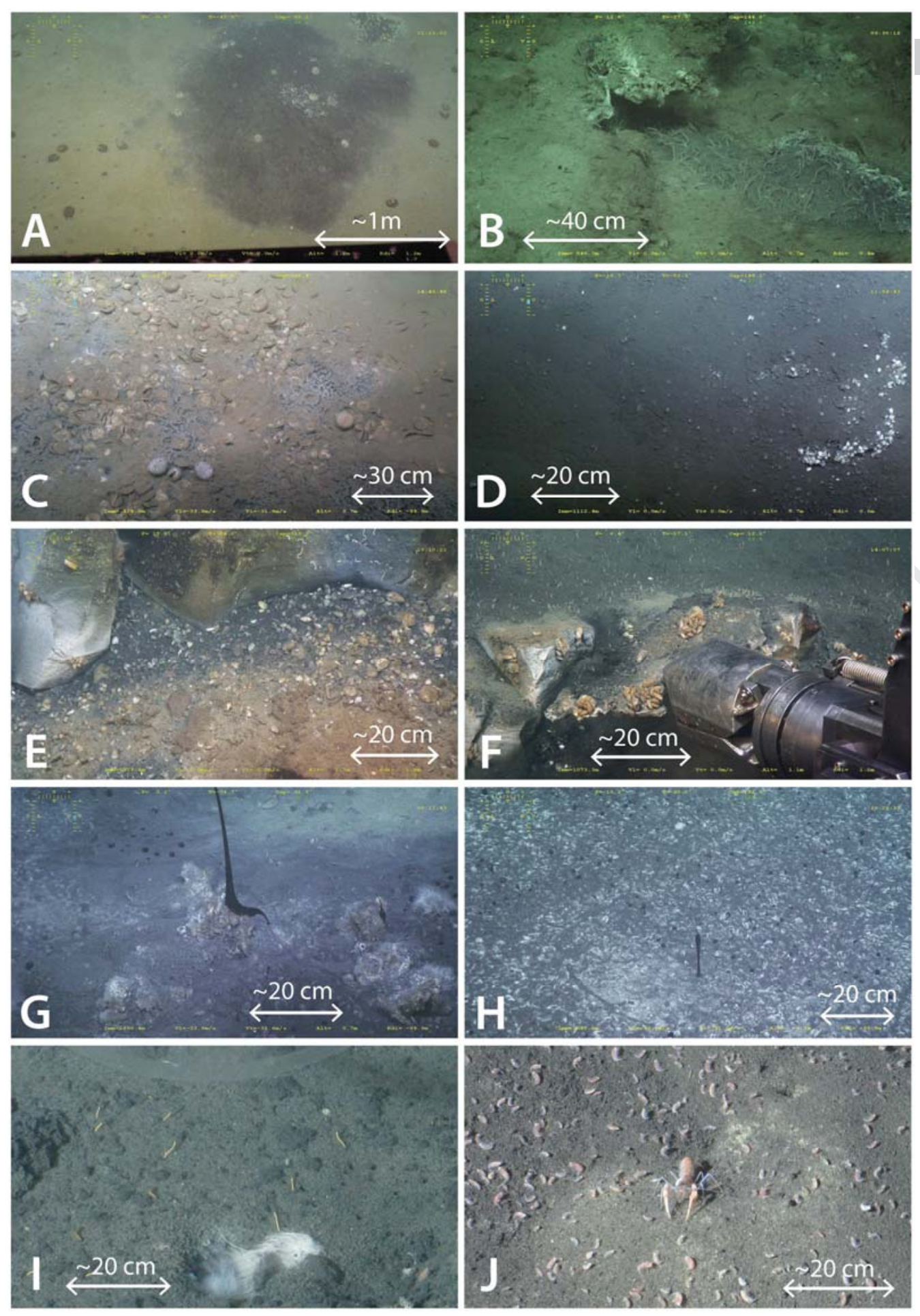

Plate I: Near-bottom seafloor photos taken by the Victor ROV during the Marsite Cruise dives (2014): A) Central High, focus on black patch with dead urchins and Ampharetidae inside the patch; B) Central High, Tubicolous polychaetes on reduced sediment; C) Central High, dead Vesicomyidae; D) Tekirdağ SE, dead and live Vesicomyidae on reduced sediment; E) Tekirdağ NW, accumulation of bivalve shells on reduced sediment, blocks of Keşan Formation in the background; F) Tekirdağ NW, Bathymodiolinae fixed on blocks of Keşan Formation and Tubicolous polychaetes on reduced sediment; G) Tekirdağ NW, on Dallas site, oil escape with Bathymodiolinae at the foot; H) Tekirdağ NW, NE from Dallas site, pearls of oil with vesicomyid bivalve shells and live ones on the bottom; I) Çinarcik Basin, vagile worms and filament of bacterial mat on fluid escapes; J) Çinarcik Basin, Amphipods and Axiidae crustaceans on the bottom. 
Joumal Pre-proot

ROV navigation acquisition was performed using an Ultra-Short BaseLine (USBL) and dead-reckoning navigation system (Sen et al., 2016), leading to an accuracy of location at the seafloor of less than $10 \mathrm{~m}$. To correlate the Marsite dive tracks with pre-existing data, AUV bathymetry and backscatter data (Grall et al., 2018b) and structural maps (Grall et al., 2018a), some minor shifts of AUV-derived maps were made, on a zone-by-zone basis, to achieve best fit of data. All data (including dive tracks, points of sampling and local structures) were integrated in a single referential framework using the ArcGis software. The ADELIE software (C Ifremer) allowed us to visualize the videos and georeference the observations made along the track of the dives.

\section{Nature of seeps}

\subsection{Overview of seep characteristics and associated fauna}

The areas explored along the Marsite dives reveal varying indicators of fluid emissions on the seafloor (Table I in supplementary material): dark reduced sediment patches, bacterial mats, chemosynthetic and typical benthic fauna (Plate I), active and inactive carbonate crusts and chimneys, continuous and discontinuous gas and oil escapes from the seafloor with different strengths of flow and brackish and brine waters (see video of supplementary material).

A wide size range characterizes the black sulphidic sediment sub-rounded patches. The reduced zones range from 2 $\mathrm{m}$ to several hundred meters in diameter, some distributed in clusters covering up to several hundred square meters. They can be associated with authigenic carbonate crusts, chimneys or fluid emissions or a combination of both. In some areas, black patches elongate along the slope direction. Often, but not always, bacterial mats are present on the black patches or limited to their rim. In some areas, just beneath the surface of the black patches, carbonate crusts are present, buried under the sediment.

Numerous bacterial mats observed on top of some black patches have varying appearances: mats over the whole seep or concentrated just at the rim or filaments at the outlet of the fluid emission holes. Some bacteria constitute spectacular structures looking like spider webs over the seep (e.g., at 00:52' in video of supplementary material). In some places, the mats appear as very thin blankets suggesting recent or slower development in comparison with the thick bacterial layer. Their colors vary from white to orange-brown with the presence of a few translucent mats.

As previously described (Crémière et al., 2012; Çağatay et al., 2018), the areas explored during the Marsite cruise (see video of supplementary material) revealed numerous types of carbonates: organized in piles and in slabs, built as chemoherms such as on the Western High mud volcano summits; carbonates with cemented shells, carbonates presenting small granular nodules or indented edges, massive pavements of several meters high and wide, and chimneys reaching $50 \mathrm{~cm}$ in height above the seafloor. A brown or orange coating of some crusts can be linked to sediment in the matrice or presence of Fe-Mn oxy-hydroxides (Bayon et al., 2011).

The fluids escaping from the seafloor collected in the SoM are of different natures: methane, carbon dioxide, brackish water, brines, ambient seawater and oil releases (Ruffine et al., 2018a and 2018b). Free gas near the seafloor exists as natural bubbling gas and is also observed from exsolution when bubbles escape during coring in the reduced sediment. The gas bubbles escape from the seafloor through clearly visible holes or cracks of a few centimeters in size (cf. video in supplementary material). Sometimes, gas escapes are associated with the presence of carbonates, rising through the crusts. Gas flows can be continuous or discontinuous. On some gas escapes, pulses are irregular and can quickly 
change from one hole to another separated by only a few centimeters. At other seeps, pulses show a periodicity varying from $1 \mathrm{~s}$ (e.g., Central High at the summit) to, $120 \mathrm{~s}$ (e.g., Central High on the SE slope). Fluids can also be composed of oil. The oil escapes can take the form of whips tethered to the substrate expelled into the water column as at the Dallas site or as black beads rising from a reduced patch into the water column.

Several symbiont-bearing bivalve families were observed in seep habitats based on seafloor images. Small Bathymodiolinae mussels were observed but not sampled on hard ground (carbonate crusts or solid outcrops) in the Western High and along the northwestern and south-eastern parts of the Tekirdağ Basin (Plate I -F and G). The other observed living bivalves along the dives can be visually identified as Vesicomyidae (Plate I -C, D, E and H). Lucinid shells were also observed, lying on the seafloor but their burying behavior precludes seeing them alive on images. Other abundant benthic fauna at seeps include tubiculous polychaetes (Plate I -B), which could include the Ampharetidae family as previously sampled in reduced sediments and analyzed by Ritt et al., (2010). Never previously sampled in the SoM, tubiculous and symbiont-bearing Siboglinidae were observed. Unidentified vagile polychaetes (Plate I-I) and amphipods (Plate I-J) are also abundant at the cold seep sites. Spatangoida urchins extensively cover the sediment, but are usually dead in reduced sediments, and therefore do not seem to be adapted to a sulfide-rich environment (Plate I-A).

\subsection{ROV-based seep description (site by site)}

\subsubsection{Central High ( $820 \mathrm{~m}$ to $320 \mathrm{~m}$ water depth)}

Compared to what has previously been achieved in this area, dive DV592-01 (Figures 1 and 2) extends observations by exploring the entire high structure from west $\left(28^{\circ} 31^{\prime} \mathrm{E}\right)$ to east $\left(28^{\circ} 38^{\prime} \mathrm{E}\right)$. The activity already described at the summit of the high (Dupré et al., 2015), is still as strong with more than 10 fluid escapes, gas bubbles being sometimes expelled through massive carbonates (C11 site, Figure 2B and C). Black patches, localized and small in diameter $(<3-5 \mathrm{~m})$, are colonized by bacterial mats of a specific spider web network appearance (e.g., at 00:50' in video of supplementary material). Around some vent apertures, dense white bacterial filaments are also present, moving with the pulse of fluid flow (e.g., at $00: 35^{\prime}$ in the video of the supplementary material). The area is highly sedimented and carbonates appear as tabular crusts of a few square meters with cropped edges, or sometimes just outcropping from the sediment surface. Localized in the NW slope, a $100 \mathrm{~m}$ by $200 \mathrm{~m}$ depression (see "Dep" in Figure 2B) was visited in situ for the first time. It is linked to a small mass wasting (Dupré et al., 2015) and presents numerous carbonate crusts. 


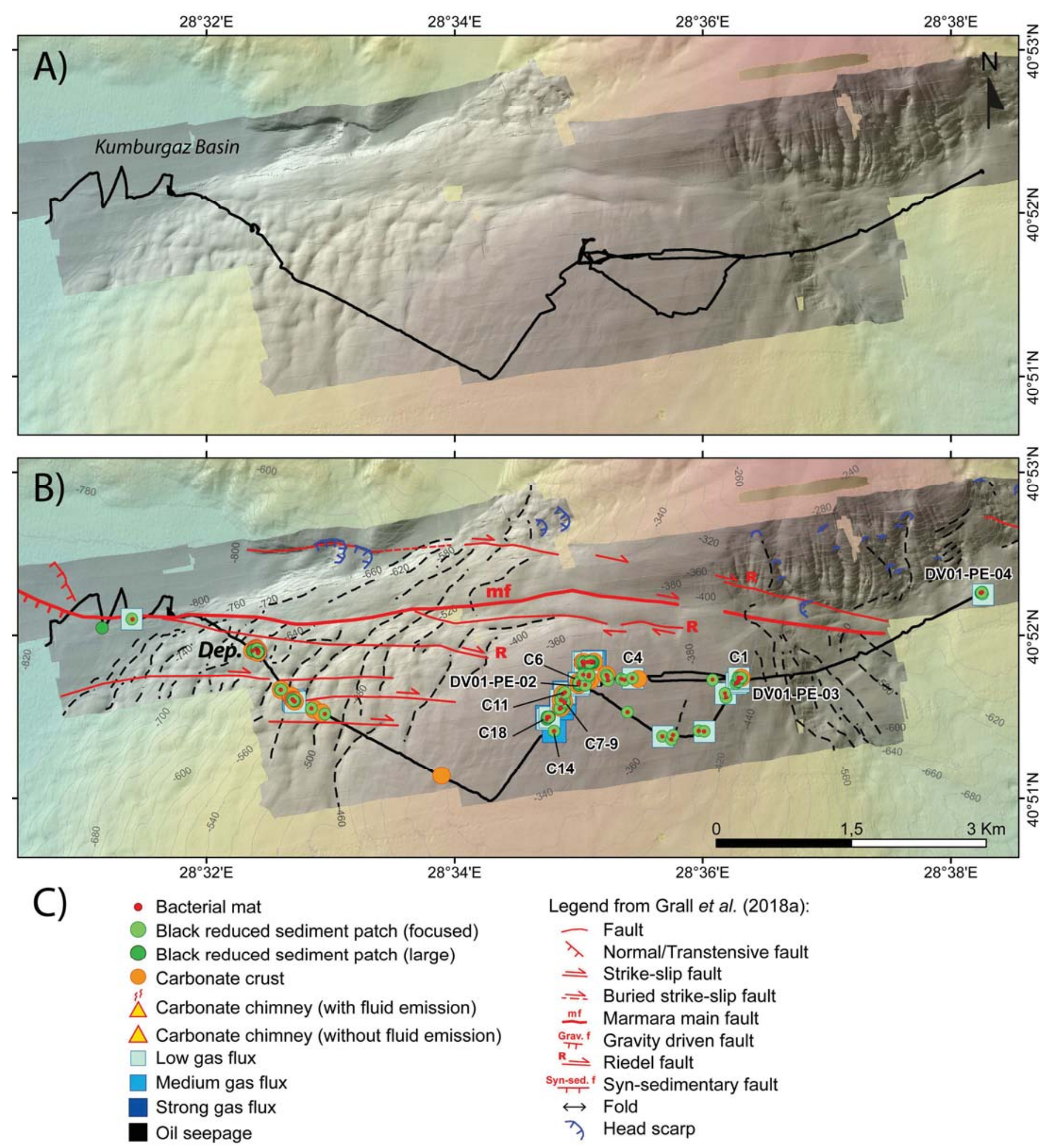

Figure 2: A) Illuminated high-resolution bathymetric maps from AUV data (EM2000, $200 \mathrm{kHz}$, Marmesonet cruise 2009, Grall et al., 2018b) of the Central High with track of dive DV592-01 in black, for location see Figure 1. B) Seep indications along the dive track and geo-morphostructure interpretations from Grall et al., (2018a). PE stands for Pegaz sampling, C) Legend of seeps and structures.

On the northwest slope, not far from this small mass wasting, discontinuous escapes of low flow rate occur along $\mathrm{N} 100^{\circ}$ oriented faults. In the NE slope, a few localized seeps, covered by bacterial mats, emit low or discontinuous 
gas escapes (Site C1 - Figure 2B). Within vicinity of the MMF, the sea bottom is highly sedimented. On its NW part, only one low flux gas emission was observed coupled with black patches. In the opposite explored part, a few irregular and low flux gas escapes are also present and related to the fault. It is important to notice that little seepage evidence connected to the MMF is observed here and the absence of bacterial mats and carbonate crusts may indicate very recent fluid expels. No carbonate chimneys or oil escapes were observed over the entire explored area. Outside the seepages, numerous dead or live urchins inhabit the seafloor. Vesicomyidae bivalves are present in high densities at some sites (C 7-9 figure 2B, Plate I-C), or appear more scattered such as at the summit of the Central High and in the mass-wasting of the NW slope. Shells of Lucinid clams are present at the summit and possibly at the NE visited part of the MMF. The black patches with a potentially high sulfide concentration along the MMF and in the Central High NW slope host polychaete worms which could be ampharetids (Plate I-B). No Bathymodiolinae bivalves were observed throughout the area explored by dive DV592-01.

\subsubsection{Western High (720 m to $600 \mathrm{~m}$ water depth)}

On the Western High, three main sites hosting seeps were visited during dive DV593-02 (Figure 1, 3A and 3B): the mud volcanoes located north of the Main Marmara Fault, some segments of the MMF over $3 \mathrm{~km}$ and areas located south and $700 \mathrm{~m}$ from the MMF in the damage zone. Over the two outcropping mounds oriented NE-SW corresponding to mud volcanoes (Figure 3C), the dominant characteristic is the presence of carbonate crusts over the two mounds with the highest density at the summits (see 01:38' on video of supplementary material). Their shapes and constitutions vary: jagged with nodules, structured in tabular superimposed platters (see 02:27' on video of supplementary material) or cemented by dead bivalve (Çağatay et al., 2018). No major changes have occurred between 2007 (Henry et al., 2007b) and 2014 (Dupré et al., 2015; Grall et al., 2018a) with gas emissions on both mud volcanoes and denser flux escapes at the summits of the mounds (Table I in supplementary material). It is important to note that on the northeastern flank of the northern mud volcano, discontinuous flows of oil droplets are still escaping (Figure 3C) (Henry et al., 2007b). Particularly numerous on the northeast part of the northern mud volcano, focused and extensive black patches are sometimes elongated along the slope. Along the $3 \mathrm{~km}$ of the MMF followed by the ROV, segments with reduced sediments, bacterial mats, few authigenic carbonate crusts and low fluid emissions occurring directly over the black patches, alternate with segments where there is no seepage evidence. Located $80 \mathrm{~m}$ north of the MMF, an area of $10 \mathrm{~m}$ in diameter includes numerous localized patches of reduced sediment with low discontinuous gas bubbles releases (Site B in Figure 3B). Based on strong AUV seafloor backscatter anomalies (Figure 3D), exploration $700 \mathrm{~m}$ from the MMF in the southwest revealed seep areas of black patches with bacterial mats, local authigenic carbonate crusts and scattered continuous or discontinuous fluid escapes. 

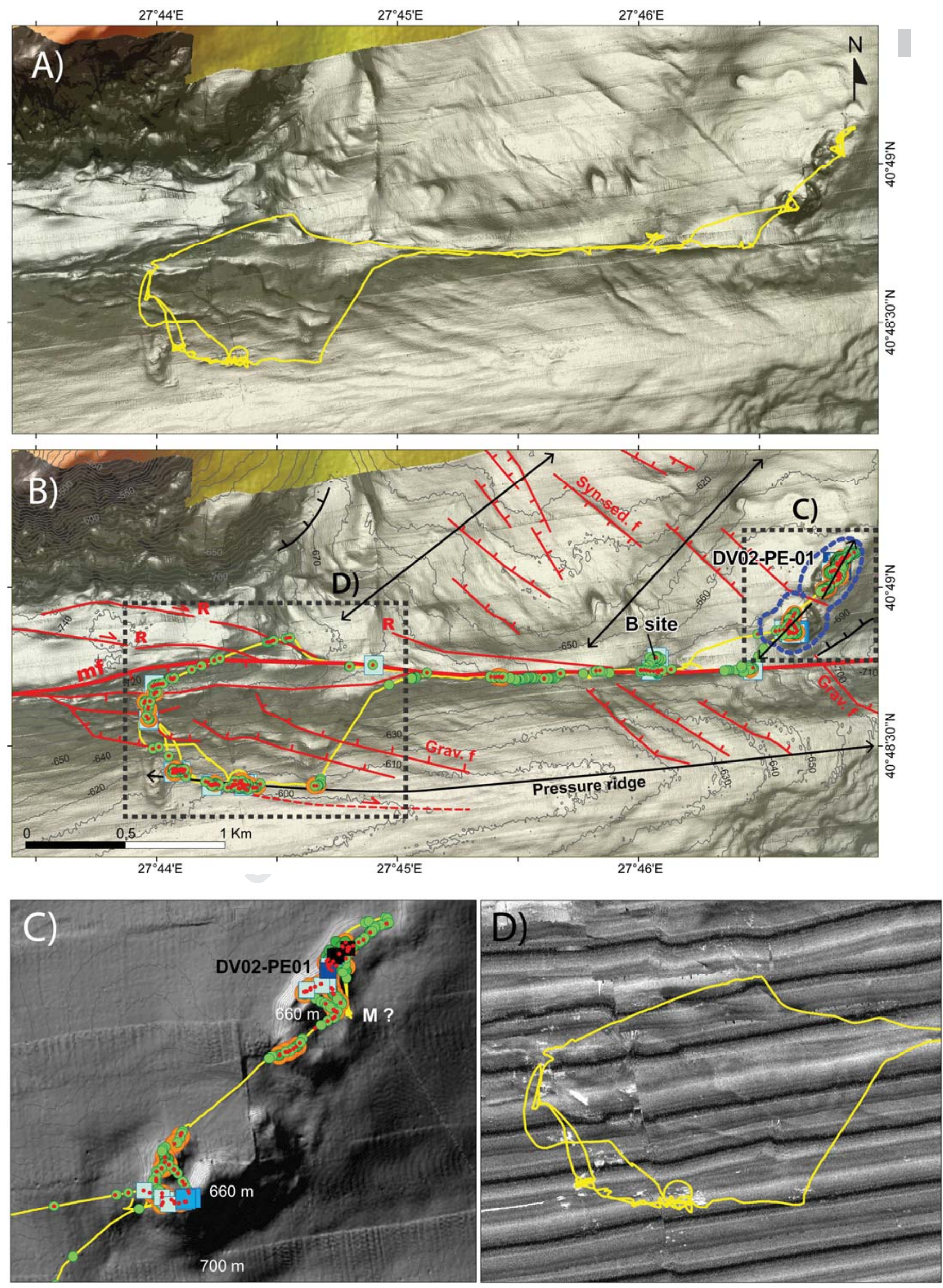
345 Figure 3: A) Illuminated high-resolution bathymetric map from AUV data (Marmesonet cruise - 2009) of Western

346 High with track of the dive DV592-02 in yellow. For location see Figure 1. B) Seep indications along the dive track 347 and geo-morphostructure interpretations from Grall et al., (2018a), PE stands for Pegaz sampling. For legend of seeps 348 and structures see Figure 2. C) Zoom on the seeps of mud volcanoes on illuminated high-resolution bathymetric map 349 (EM 2000, 200 kHz, Marmesonet cruise - 2009, Grall et al., 2018b); Dive track 593-02 in yellow line; M for Mussels. 350 D) Seafloor backscatter image (EM 2000, $200 \mathrm{kHz}$ ) focused on the seeps in the south of the MMF with dive track 351 DV593-02 (yellow line); White areas stand for strong backscatter amplitudes.

It is important to mention that the fauna over the Western High seems less abundant than elsewhere in the SoM but appears more diverse. Reduced sediments host two different morphotypes of tubiculous polychaetes even in patches affected by oil drops. Vesicomyids are present in low quantities but many shells, e.g., lucinid shells, are present at bubbling sites on the mud volcanoes and along the MMF. Probable live vesicomyids inhabit the south damage area of the fault. Out of the seeping areas, hemipelagic sediment is brown, with bioturbation features and a profusion of live urchins. Dead urchins were observed mostly in areas where bubble flow is higher and/or oil escapes are present. In areas of oil seeping, fish of the Macrouridae family were frequently observed. Mussels may colonize the southern mud volcano but their presence cannot be definitely confirmed due to poor image quality.

Two dives were performed in this basin: dive DV594-03 on its northwestern border along the foot of the slope (Figure 1, 4A, 4B and 4C) and dive DV595-04 on the southern border of the basin along the MMF scarp (Figure 1 and 5). 

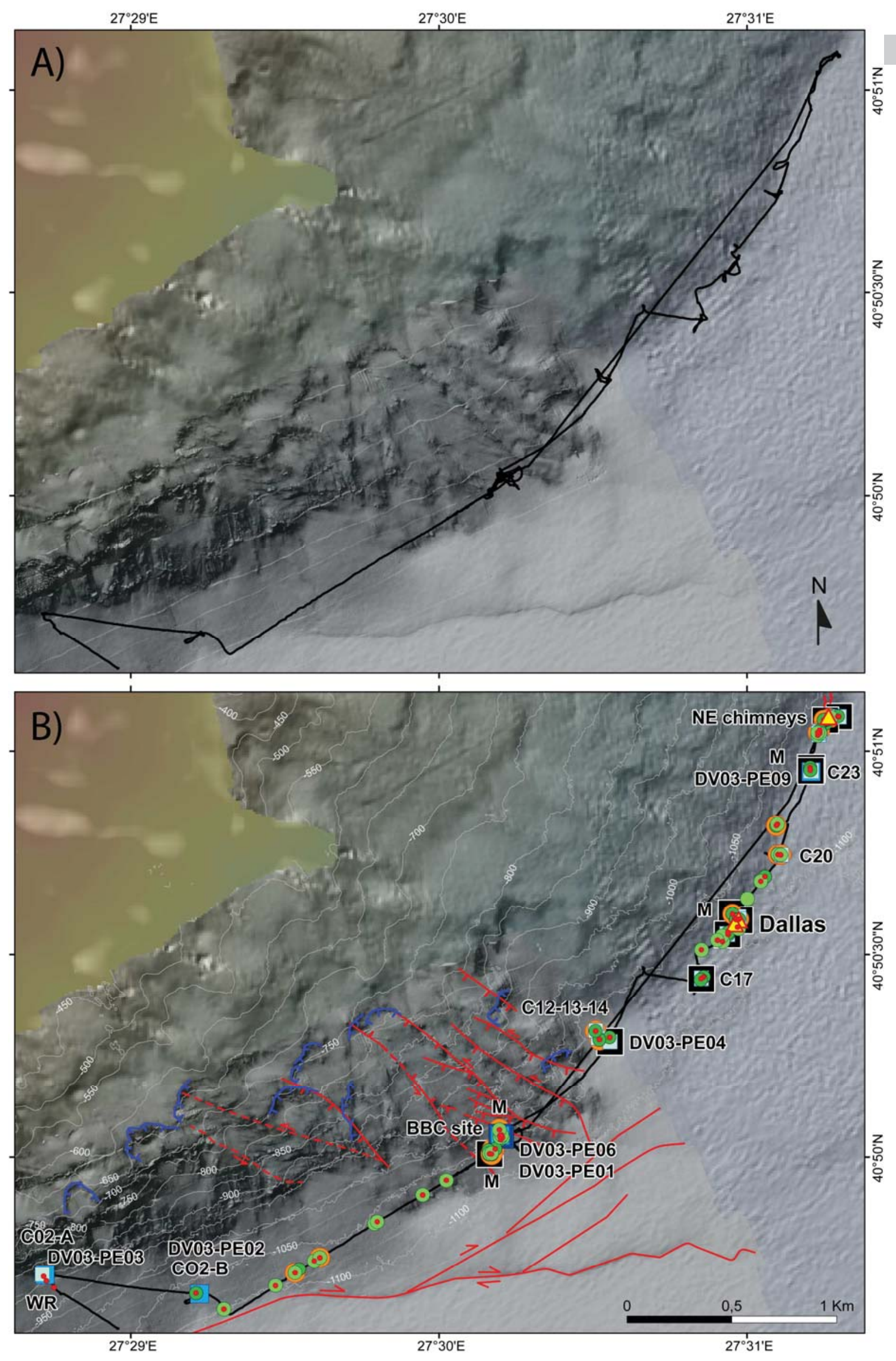


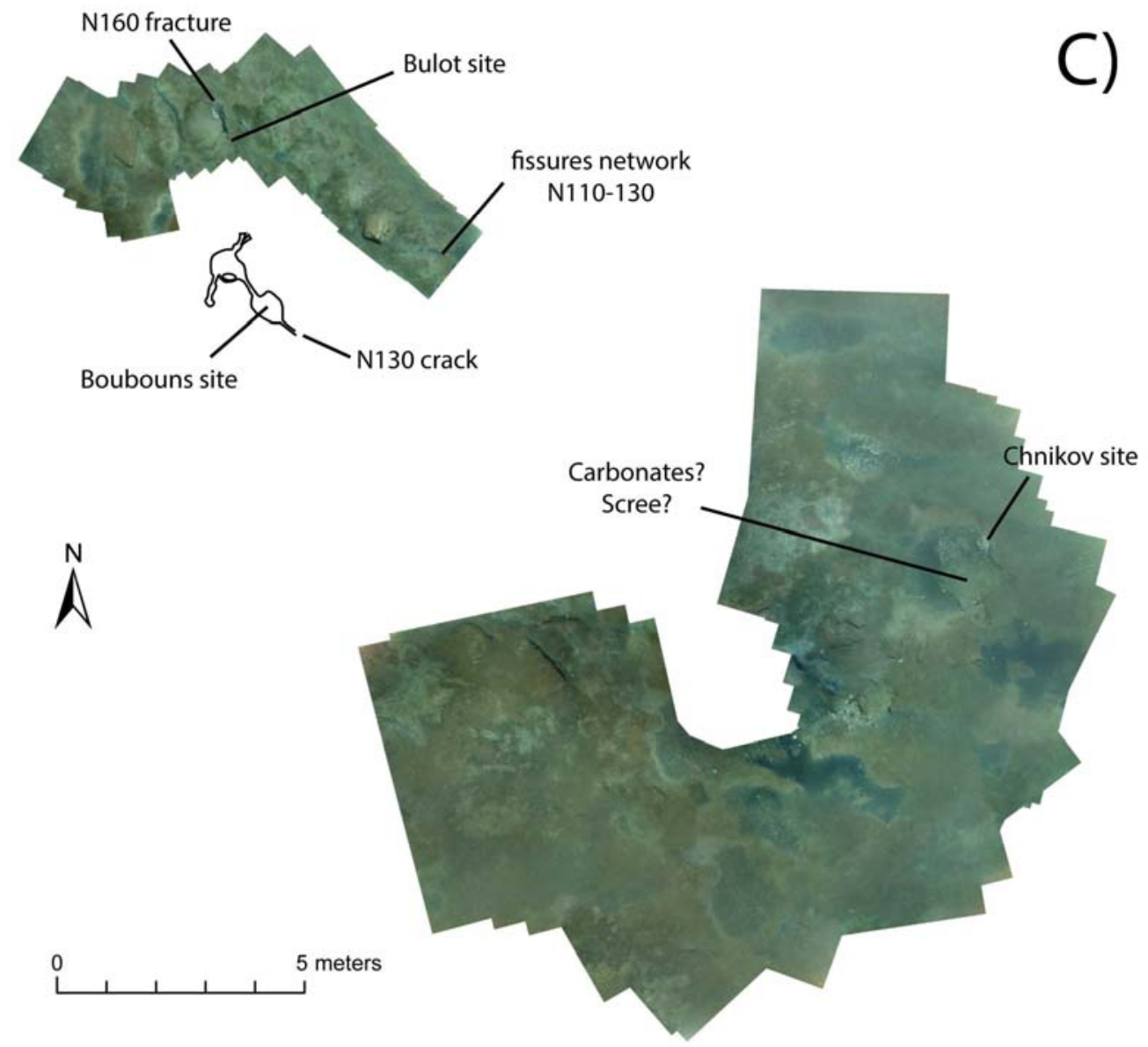

Figure 4: A) Illuminated high-resolution bathymetric map from AUV data (Marmesonet cruise - 2009) of the NW Tekirdağ Basin. Track of dive DV594-03 in black. For location see Figure 1. B) Seep indications along the dive track and geo-morphostructure interpretations from Grall et al., (2018a). PE stands for Pegaz sampling, M for Mussels, WR for White River (see text for explanations). For legend of seeps and structures, see Figure 2. C) Near-bottom photo mosaic issued from videos of the $\mathrm{BBC}$ site.

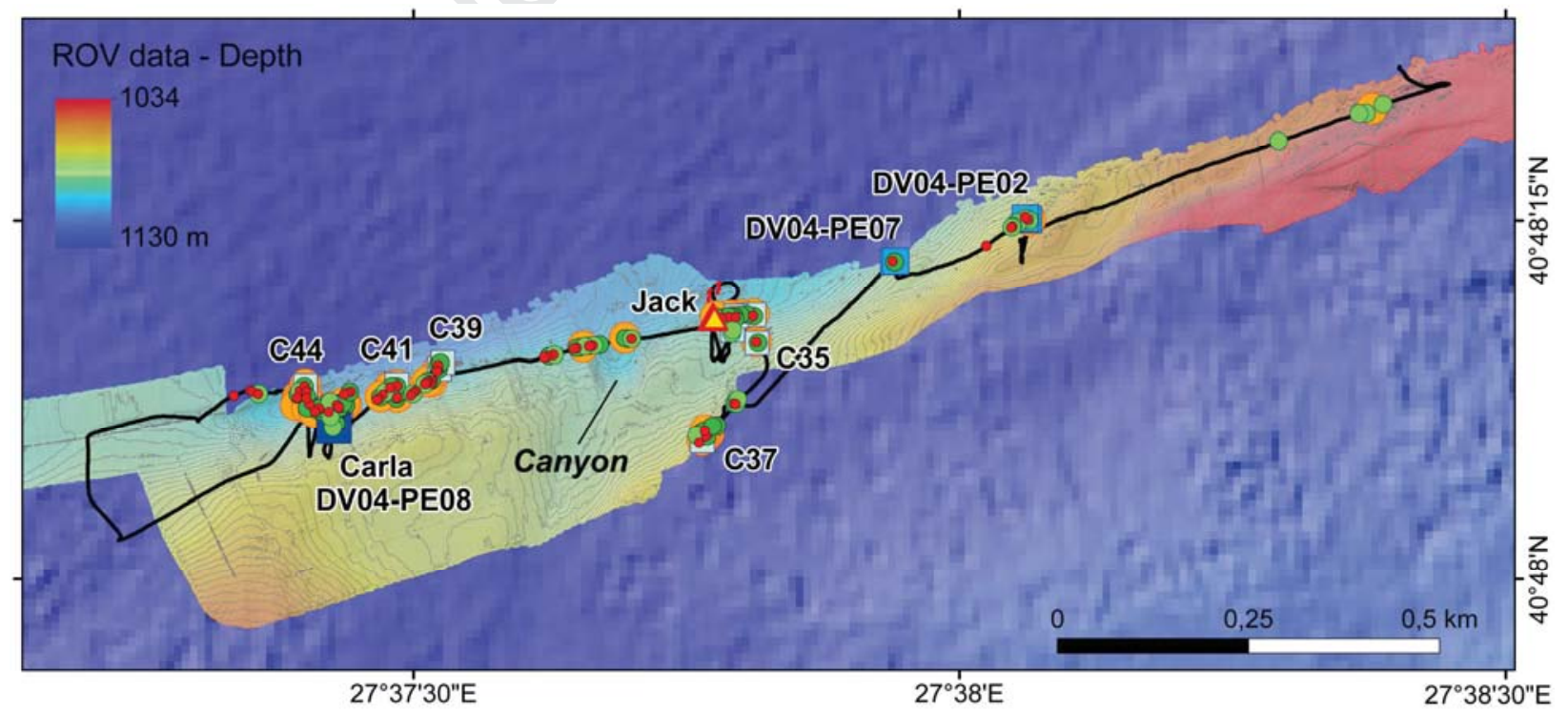

Figure 5: Marsite cruise seeps on the high-resolution bathymetric map from ROV data (Marmarascarp cruise; Armijo et al., 2005) of the SE Tekirdağ Basin. Track of dive DV595-04 in black with indices of seep along the dive track, PE stands for Pegaz sampling. For location, see Figure 1 and for legend of seeps, see Figure 2. 
Contrary to localized past explorations (Henry et al., 2007b), the ROV survey extends observations along the NW border of the Tekirdağ Basin and emphasizes the huge diversity of seeps and ecosystems along the $6 \mathrm{~km}$ long survey (Figure 4B). At the start of the dive on the westernmost part, tens of meters long and 2 to 3 meters wide, strange white materials were seen flowing along the slope (WR in Figure 4B). Not sampled, we hypothesize, based on their appearance and movement when water is displaced by ROV, that they may be bacterial mats. Exposure of tabular blocks most likely corresponding to Keşan turbidites (described first in situ by Henry et al., 2007b) occurs very near the foot of the slope at $\sim 1070 \mathrm{~m}$ water depth. Black reduced sediments and bacterial mats concentrate between the blocks. Located in the northeastern part, never explored before, the survey shows inactive (see 03:19' on video of the supplementary material) and active chimneys, $20 \mathrm{~cm}$ in height above the seafloor that expel shimmering brackish water. Two significant points regarding fluids are that: i) continuous and discontinuous emissions from low to strong flux release $\mathrm{CH}_{4}$ and $\mathrm{CO}_{2}$ gas bubbles but also oil (Figure 4B); ii) the most active gas venting site, already explored during Marnaut cruise (Henry et al., 2007a; 2007b) and located at the crossing of the slope foot and a N140 direction, is still active. It is constituted of different vents (Bulot, Boubouns and Chnikov for the BBC cluster, Figure 4C), spread over an area of $\sim 15 \mathrm{~m}$ circumference. Located along a $2 \mathrm{~m}$ long N160 fissure, the Bulot site is a less active medium emission site compared to Chnikov and Boubouns sites. During the Marsite cruise, the highest flow rate of the SoM - 121, $327 \mathrm{mLn} \cdot \mathrm{min}^{-1}$ - was measured in a few centimeter-wide crack oriented N130 at Boubouns site (see 04:55' on the video of the supplementary material). In the eastern part of the explored area, discontinuous and continuous whips or beads (Plate I, G and H) of oil are present. A site named 'Dallas" (Plate I- G; see also 05:00' on video of the supplementary material), located at the foot of the slope, emits continuous tiny filaments of oil, 1-2 $\mathrm{cm}$ in diameter, tethered to the substrate while floating upright. Over the explored area, we observe biological diversity that is probably related to the various types of escaping fluids $\left(\mathrm{CO}_{2}, \mathrm{CH}_{4}\right.$, oil and brackish water). Near $\mathrm{CO}_{2}$-A escapes, no animals are visible but translucent bacteria are present. Near the $\mathrm{CO}_{2}$-B site, only some rare tubicolous polychaetes and fish of the Macrouridae family are observed. These are not chemosynthetic fauna. In addition, the appearance of tubicolous worms really differs to those associated with other seeps on the Tekirdağ Basin (Plate I-F), Central High (Plate I- B) and Western High areas. In contrast, near the active gas bubbling, typical fauna is composed of Vesicomyidae and Bathymodiolinae bivalves. Mytilid bivalves colonize diverse areas ranging from a site located 100 $\mathrm{m}$ from the BBC site on the Keşan outcrop, (Plate I - F) to sites close to oil discharges (Dallas seepage, Plate I- G) to areas of shimmering water from carbonate chimneys. Few living vesicomyid clams have been observed in the northeastern part of the explored area, less than $1 \mathrm{~km}$ from BBC site. More surprising, numerous dead vesicomyid clams are present at the seafloor among oil drops (Plate I- H). Lucinidae shells were only seen around the BBC site. Except on sites expulsing $\mathrm{CO}_{2}$, dense polychaetes, which could be ampharetids (Plate I-F), are found throughout the explored area, densely distributed in reduced sediment patches. Urchins are abundant over the whole area and fish of the Macrouridae family are often present where oil escapes. Hemipelagic sediments, sometimes highly bioturbated, cover the seafloor outside of the seeps.

The second explored part of the Tekirdağ Basin was the SE border of the basin (1110 m to $1060 \mathrm{~m}$ water depths), along the MMF (Figure 5). There is a clear difference between the easternmost and the central and southwestern explored parts. In the northeast, black patches of reduced sediment without bacterial mats are darker and exclusively concentrated on areas less than $2 \mathrm{~m}$ in diameter. No fluid emissions were observed even if free gas was evidenced by 
bubble escapes during the ROV's arm disturbance near the surface. Coupled with the presence of only a very few carbonate crusts, we hypothesize that the seeps on the most eastern part may be more recent than elsewhere. On the central part, the flux of gas escapes is medium and both bacterial mats and carbonate crusts are present. On the southwestern part, large black patch areas of more than $100 \mathrm{~m}^{2}$ are present. In some places, authigenic carbonate crusts appear as massive pavements of $\sim 2 \mathrm{~m}$ in height and several meters in length (see 02:00' in video of the supplementary material). In other places within the explored zone, crusts are less massive but indented along their edge or arranged in stacked plates. They sometimes present a granular appearance. Some strong gas bubble escapes are associated with the presence of massive carbonate pavements at Carla and C44 sites located at the foot of the basin slope and along the MMF. Fluid activity is still occurring through methane-derived authigenic carbonate chimneys expelling shimmering brackish waters (Tryon et al., 2010) discovered during the Marmarascarps cruise in 2002 (Armijo et al., 2005; Zitter et al., 2008), and re-explored during the Marnaut cruise in 2007 (Henry et al., 2007b). Several small carbonate chimneys of $10 \mathrm{~cm}$ to $50 \mathrm{~cm}$ high, of which the already known active "Jack-the-Smoker" (Zitter et al., 2008) (see 02:45' on video of the supplementary material) are located one hundred meters east of the canyon outlet. Outside of areas of chimneys and carbonate pavements, gas bubbles escape either continuously or discontinuously with low, medium and strong fluxes. No evidence of oil seepage was noticed throughout the exploration.

Along the explored area, chemosynthetic fauna such as bivalves and tube dwelling polychaetes were observed. Mussels are associated with high fluxes when fixed on carbonate crusts of the Carla and the C44 sites and are also present near the carbonate chimneys. Small-size vesicomyids are present within the patches of black reduced sediment (Plate I- D). Most of them seem dead but a few living individuals have been seen associated with gas bubbling at the sediment interface (e.g., C39 site). Two morphotypes of tube-dwelling polychaetes are present in patches of reduced sediment throughout the dive area and especially in the vicinity of Jack-the-Smoker. Hemipelagic sediment constituting the seabed outside the seep zones appears bioturbated with the presence of a few urchins. Corals and anemones colonize the carbonate crusts located near the Carla site and several fish were also observed near the carbonate pavements and chimneys.

\subsubsection{Cinarcik Basin (1250 $\mathrm{m}$ to $1200 \mathrm{~m}$ water depth)}

The Çinarcik Basin was explored during dive DV596-05 eastwards, from the bottom of the basin (1250 $\mathrm{m}$ in depth) to the SE border, at the foot of the slope (1250 $\mathrm{m}$ to $1200 \mathrm{~m}$ depth) (Figure 1 and 6). These two areas have very different characteristics and are separated by an area without any evidence of past and current fluid circulations. 

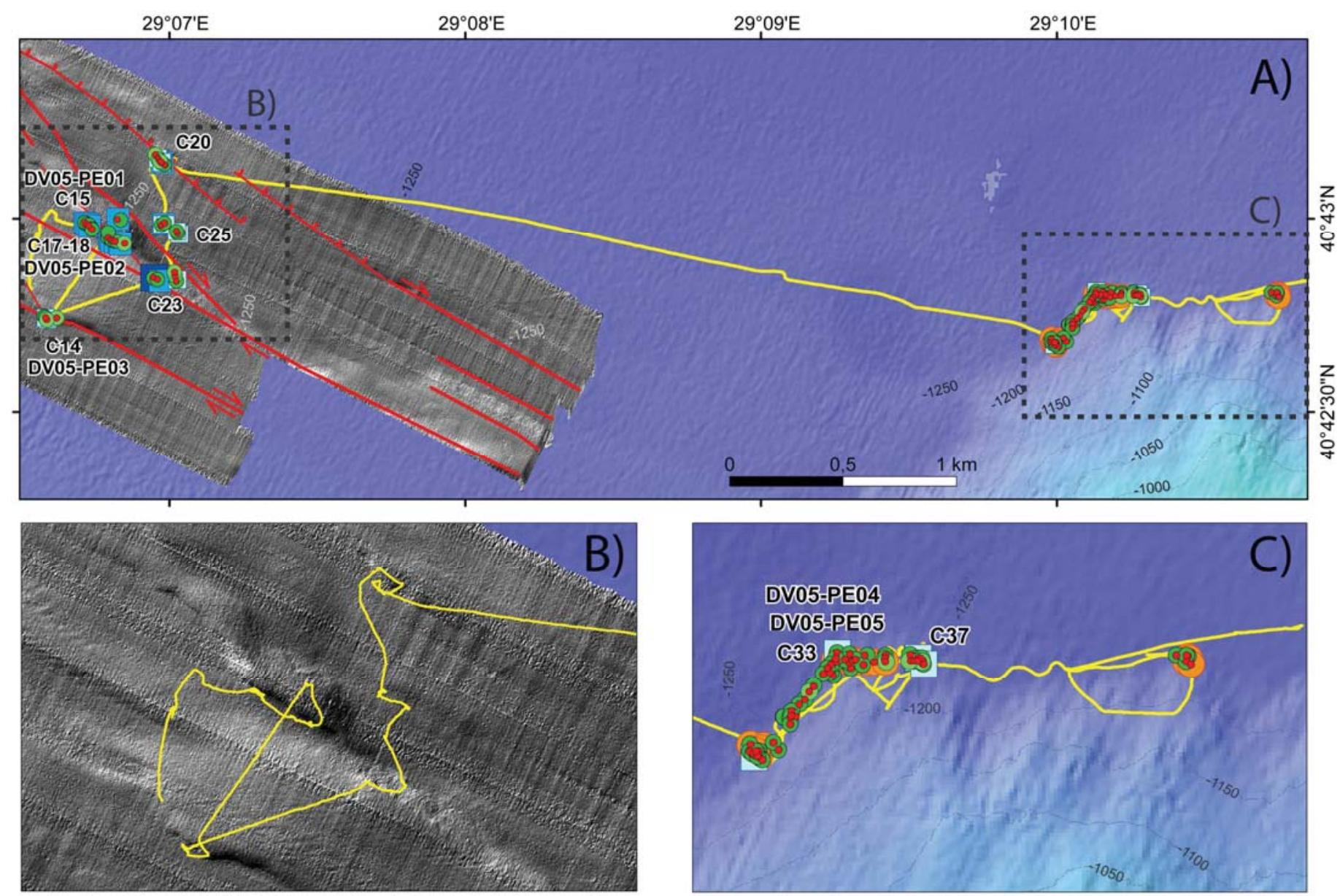

Figure 6: A) Superposed on the general colored bathymetric map is the illuminated high-resolution bathymetric map of the south part of the Çinarcik Basin from AUV data (Marmesonet cruise - 2009) with observed Marsite cruise seeps and geo-morphostructure interpretations from Grall et al., (2018a). Track of dive DV596-05 in yellow, for location see Figure 1. For legend of seeps and structures see Figure 2. B) Zoom on the explored area in the basin with dive track in yellow. C) Indices of seep along the dive track at the slope of the basin, PE stands for Pegaz sampling. For legend of seeps and structures, see Figure 2.

In the western part of the dive, where N130-140 oblique faults with normal component (Le Pichon et al., 2001; Grall et al., 2018a) are clearly visible on the high-resolution bathymetry map (Figure 6B), most seep features and gas emissions (sites C14 to C25) are focused on these fault scarps. Specific to this area, black patches of reduced sediment (see 01:12' on video of the supplementary material) can cover areas reaching $100 \mathrm{~m}^{2}$ to $200 \mathrm{~m}^{2}$ but with only a few bacterial mats at the edge of the patches and sometimes darker zones of very light material at the centre. Less frequently, the bacterial mats are organized as a network of filaments as described on the Central High. Fluids vent in a continuous or discontinuous way through holes of less than 5-10 cm wide. Numerous sites include many vents directly on patches of reduced sediment with i) low venting suddenly changing from one hole to another and ii) white bacterial filaments occasionally covering the mouth of vents. Medium and strong fluxes are also observed. In this part of the Cinarcik Basin (Figure 6A and 6B), no carbonate crusts were noticed which sharply contrasts with the slope border of the basin (Figure 6C), where the explored seeps show massive, $1 \mathrm{~m}$ to $2 \mathrm{~m}$ thick and $3 \mathrm{~m}$ to $5 \mathrm{~m}$ long, carbonate blocks, with black patches at their foot. As in the basin, at the foot of the slope (Figure 6C), huge black 
patches of reduced sediment reach more than $100 \mathrm{~m}^{2}$ and are oriented $\mathrm{N} 140^{\circ}$. No oil escapes were seen over the explored area of the Çinarcik Basin.

As for the geological aspect, the biology is strongly contrasted between the two explored areas. Even if two morphotypes of polychaetes live on the seep, especially on the black reduced sediment areas, long tubeworms resembling siboglinids were only observed fixed on carbonate crusts of the slope area. The others polychaetes observed in abundance are vagile worms (Plate I- I). The morphotypes previously described on the Tekirdağ Basin, Central and Western highs, and thought to be Ampharetidae were not observed on Çinarcik Basin. Only present in the eastern part, some Axiidae crustaceans (Plate I- J; Laure Corbari, pers. com) were observed together with thousands of amphipods above carbonate crusts. This site was not investigated previously during Marmarascarps and Marnaut dives. Anemones and coral are fixed on carbonates. No bivalves were observed over the dive but Teichert et al., (2018) described the presence of (vesicomyid) clam shells in sediment cores sampled from the basin at the site of normal faults $\mathrm{N} 130^{\circ}-\mathrm{N} 140^{\circ}$. Hemipelagic brown sediment constitutes the sea bottom between seeps. Darker and browner, its color is different from the sediment elsewhere in the SoM, especially near the "Amphipod site" where it appears more granular and reddish. Strangely, the area is densely populated by benthic fauna which strongly differs from other areas of the SoM and particularly from typical worldwide cold seep fauna (except those we describe as possible siboglinids).

\section{Discussion}

Systematic water column mapping (Dupré et al., 2015) has resulted in an accurate spatial distribution of SoM gas escapes, showing that emissions are spatially controlled by faults and inherited faults, fracture networks in connection with the MMF, nature and thickness of sediments, landslides and obviously, connectivity between the seafloor and gas sources. The results of the Marsite cruise confirm that the majority of seeps perfectly match with the gas bubble detected previously in the water column by Dupré et al., (2015). Numerous significant escape sites discovered during previous cruises (Armijo et al., 2005; Henry et al., 2007b; Géli et al., 2018), e.g., the BBC sites (Figure 4C), Jack-theSmoker in Tekirdağ Basin, the summit of Central High, the mud volcanoes of the Western High and seeps associated with the normal faults in Çinarcik Basin are still active 7 to 12 years later. Seep activity seems well-rooted over all the studied areas and locally connected to tectonic and sedimentological processes (Dupré et al. 2015; Grall et al., 2018a; Henry et al., 2018). Structural control of seeps has already been established in many other cold seep contexts (Orange et al., 1999; Eichhubl et al., 2000; Law et al., 2010; Sun et al., 2012; Lichtschlag et al., 2018). The faults, fracture networks and up-fault permeability are the most important factors controlling distribution and temporal and spatial variability of seeps (Talukder, 2012). Seep plumbing systems are faults, fractures, bedding planes along crests of fold and sedimentary ridges and flanks and margins of canyons (Talukder, 2012). Seeps are also found linked to head scarps of submarine landslides (Naudts et al., 2006; Law et al., 2010) or to folding as in Monterey Bay (Orange et al., 1999). In transpressional segments in strike-slip fault systems offshore southern California, Maloney et al., (2015) emphasize the role of localized fault segment boundaries on the distribution of fluid expulsion sites and associated seep habitats. At the seafloor of the SoM, similar strong correlations between tectonic structures, sedimentary facies and gas seepage and methane concentration have been described (Zitter et al., 2008; Gasperini et al., 2012; Géli et al., 2018; Grall et al., 2018a; Henry et al., 2018). Based on seafloor observations previously described and confirmed in 
this current study, structures and structure intersections where seeps are present consist of faults, slumps, canyons, foot of slopes, outlets of gullies, scars, fault intersections, fault and canyon intersections, basin edges, landslide limits and folds (Figures 2B, 3B, 4B, 5 and 6A).

\subsection{Control on seep distribution}

\section{Seeps along the Main Marmara Fault and in relation with the fault system}

The Marsite ROV explorations have followed the MMF in four different morphological areas: Central High, Western High and the southern and northwestern parts of the Tekirdağ Basin, showing that seep indicators are observed along the MMF but also in its damage area defined as a brittle deformation zone developed around the principal fault plane (Henry et al., 2018). However, this activity is variable depending on the site. The explored areas furthest from the MMF where fluid activity is present are located in the Western and Central highs, $800 \mathrm{~m}$ and $2000 \mathrm{~m}$ from the MMF, respectively. Henry et al., (2018) retain $910 \mathrm{~m}$ as defining the half-width of the swath of seep activity associated with faults in the Western High area, and $2 \mathrm{~km}$ for the Central High, the width of the deformation zones matching that of the swath of water column acoustic anomalies (Henry et al., 2018). Following exactly the seafloor trace of the main fault, fluid activity is more intense on the southern border of the Tekirdağ Basin compared with segments in the Western and Central highs where fluid activity is sparse and low. At the southern border of the Tekirdağ Basin, numerous medium to strong gas escapes reflect this intense activity with impressive carbonate pavements observed at the seafloor possibly testifying long-term activity (Figure 4B). In contrast, on the most eastern part of the same dive located along the southern Tekirdağ Basin edge, carbonate crusts are absent despite strong fluid escapes. Along the part of the MMF crossing or bordering the Western and Central highs, fluid activity is not uniformly distributed, with a juxtaposition of active and inactive "segments" extending from $50 \mathrm{~m}$ to $150 \mathrm{~m}$ long for the active ones and from $200 \mathrm{~m}$ to $400 \mathrm{~m}$ long for the dormant segments. These active and inactive segments are also irregularly spaced, between $200 \mathrm{~m}$ and $400 \mathrm{~m}$ from each other (Figure 3B). Where fluid activity exists, it is however weak, only characterized by few bacterial mats with discontinuous low flow rates. Along inactive segments of the MMF in the Western High, authigenic carbonate crusts are rare or absent. On the SE Tekirdağ Basin edge, in the NE part of the dive we also observe a lack of carbonate crusts but strong fluid emissions. The absence of carbonate crusts in these two different contexts can be respectively explained by too a low and too intermittent activity or recent initiation. Alternatively, the authigenic carbonate crusts might be buried. In the Western High, south of the MMF (Figure 3B and 3D), seeps are present $800 \mathrm{~m}$ from the main fault, related to the fold parallel to the MMF and defined as a pressure ridge (Grall et al., 2018a). In this part of the NAF, significant gas occurrence within the shallow sediment $(<300 \mathrm{~m})$ was noticed, trapped in the crests of anticlines and adjacent to faults (Thomas et al., 2012; Saritas et al., 2018). In addition to the MMF and its damage zone, other structures focalized fluid escapes. In the shear zone on the north of the MMF, fluid activity expressed as gas and oil seapages are focused on the mud volcanoes due to overpressure of gassy sediments (Saritas et al., 2018).

\section{Seeps off the MMF system promoted by structure intersections}

Away from the MMF and its damage zone, our study confirms that seeps are mainly localized at the foot of the slope, outlets of gullies and gully crossroads They are also often clustered at faults or at the intersection of two sets of faults as the crossing of structures helps circulation and expulsion of fluids: e.g., meeting point of $\mathrm{N} 110^{\circ}$ faulting and 
sediment waves of downslope creep (Central High), intersection of the MMF and N110 Riedel feature (Western High, site B; Figure 3B), outlet of a structurally controlled gully bounded by two subsidiary $\mathrm{N} 135^{\circ}$ faults (BBC site, Tekirdağ Basin) (Grall et al., 2018a), crossroad between the MMF, foot of slope main canyon outlet (Zitter et al., 2008), intersections of $\mathrm{N} 135^{\circ}$ oblique faults and $\mathrm{N} 115^{\circ}$ strike-slip faults (Çinarcik Basin, Figure 6A and B).

In the southwest part of the Çinarcik Basin, numerous small N130-140 trending oblique faults with normal component cut through shallow sediments with generally little vertical displacements. These small faults, according to high-resolution bathymetric data, display an "en echelon" pattern (Le Pichon et al., 2001; Armijo et al., 2002; Laigle et al., 2008). Supporting previous studies based on the few in situ observations available, our study shows that gas escapes occur in the basin exclusively through this system of oblique faults. In contrast, at the foot of slope the expressions of seeps are very different. These two contexts, separated by only $4 \mathrm{~km}$, show high diversity of morphology and ecosystems: presence of carbonate crusts or not, focused or large black patches, exclusive fauna, presence of densely distributed species (e.g., amphipods). Within the Çinarcik basin (Figure 6A), no authigenic carbonate crusts were evidenced, seeps are focused, bacterial mats are uncommon and gas fluxes range from low to strong. Seeps into the basin appear to be recent. In contrast, along the basin edge (Figure 6C) seeps are widespread with massive carbonate crusts and varied and dense faunal communities. At this position, methane seepage and authigenic carbonate formation have been active for at least the last 175-295 years B.P (Teichert et al., 2018). In addition, in Çinarcik Basin, two major earthquakes (in 1766 and 1754; Ambraseys and Jackson, 2000) potentially triggered the increased seepage of methane (Teichert et al., 2018). The 1894 Yalova (M 7) earthquake probably produced a large fault at the southern edge of Çinarcik Basin, south of our study site (Armijo et al., 2005). Similarly, Armijo et al., (2005) have proposed the occurrence of successive earthquake ruptures on the SE Tekirdag fault, the chimneys probably being located on a recent ruptured segment, possibly due to the 1912 Ganos earthquake (Zitter et al., 2008).

\section{Seeps and sedimentary feature interactions}

To explain why the density of gas is higher on basin edges as on the SE Tekirdağ and Çinarcik borders, lateral updip migration along sedimentary discontinuities toward basin edges has been suggested (Dupré et al., 2015; Grall et al., 2018a). The Tekirdağ and Çinarcik basins have a stratified sediment infill of hemipelagic muds and turbidites (Beck et al., 2007; Çağatay et al., 2000). On the NW part of the Tekirdağ Basin, the outcrops are composed of the Keşan Turbidite Formation and some seeps are located at the stratigraphic discontinuities of this formation. The Central High sits on top of an erosional unconformity (Imren et al., 2001) and undulations on the flanks of basement highs is explained by gravity-driven downslope creep increased by sedimentation (Shillington et al., 2012). Here, sedimentary processes dominate and even if seepage and fluid escapes are associated with $\mathrm{N} 110^{\circ}$ faults and the presence of smallmass wasting at the western flank of the Central High, gas vents are mainly localized at the summit of the high, where no major outcropping fault exists and where more than 10 fluid escapes have been observed in situ and described over an area of $1200 \mathrm{~m}$ by $1200 \mathrm{~m}$ (Figure 2B).

As in the Santa Barbara Basin, where Echhubl et al., (2000) suggest a structural control on mass wasting imposed by upward fluid migration similarly some seeps along the slope of the Çinarcik Basin have been related to mass wasting (Zitter et al., 2012). Increased fluid seepage and the resulting intensification in pore-fluid pressure may raise slope 
instability and induce slumping (Orange and Breen, 1992). Slope instability may be enhanced by subsurface structure localizing fluid seepage, thus controlling the location of slumps (Echhubl et al., 2000).

On the SE border of Tekirdağ Basin (Figure 5), the group of carbonate chimneys and fluid escapes from other seeps are located along the MMF, $100 \mathrm{~m}$ from the mouth of a major canyon. In the mouth of the canyon, seep indications like black patches of reduced sediment and bacterial mats and carbonate crusts were also observed. The fact that canyons, possibly mainly filled by fine-grained sediments, serve as effective seals and favor gas accumulation at their boundaries, has been discussed in another context (Sun et al., 2012; Dennielou et al., 2017). In Monterey Bay, the presence of seeps within canyons in highly fractured regions implies that faults (through fracture permeability) may control fluid migration from depth, but that surficial geomorphology (canyons) controls the locus of fluid expulsion at the surface (Orange et al., 1999).

\subsection{Controls on fauna distribution}

Different factors interact at cold seeps (Talukder, 2012) to promote the settlement of chemosynthetic communities (Sibuet and Olu, 2002). The intensity of flux, the concentrations and compositions of fluids and the sedimentary environment are among the critical factors directly impacting seep morphology (Talukder, 2012) and thus fauna settling. Symbiont-bearing taxa are indeed distributed along fluid flow gradients according to the type of symbiosis they are associated with, because of different symbiont requirements. Invertebrates associated with sulfide-oxidizing bacteria (e.g., vesicomyids, lucinids, or siboglinid tubeworms), require sulfide production which occurs by anaerobic methane oxidation in low to moderate fluid flow allowing seawater sulfate penetration in surface sediments (Olu et al., 1997; Sahling et al., 2002; Niemann et al., 2006; Ritt et al., 2010). Nevertheless, high methane fluid flux, and areas with high methane concentrations, allow for the settlement of invertebrates associated with methanotrophic bacteria, such as Bathymodiolinae mussels encountered at seeps (Bergquist et al., 2005; Mau et al., 2006; Olu et al., 2007), or more rarely, chladorizid sponges (Olu et al., 1997; Rubin-Blum et al., 2019). Most of the symbiont-bearing taxa encountered and previously sampled in the Marmara Sea, is characterized by thiotrophic symbioses, therefore requiring hydrogen sulfide in the upper sediment layers. This is the case for the vesicomyids Isorropodon perplexum previously sampled in soft sediments of the Central Basin also known from other cold seep sites in the Eastern Mediterranean Sea and the lucinid Lucinoma kazani and Myrtea amorpha, previously sampled in the SoM, but also in other cold seeps such as in the Anaximander Mountains where L. kazani was first described (Salas \& Woodside, 2002). As observed by transmission electron microscopy (TEM) and/or isotopic values (Salas and Woodside, 2002; Olu-Le Roy et al., 2004) these symbioses are confirmed for all vesicomyids (of the sub-family Pliocardiins) living in reduced sediments at cold seeps, and for the studied cold seep lucinids. The mytilid Idas simpsoni (Idas sp. Nov in Ritt et al., 2010) seem to harbor only one symbiont type, which is thiotrophic (Ritt et al., 2012b), in agreement with the molecular study of Idas simsponi from organic remains in the Western Mediterranean and Atlantic (Laming et al., 2015). However, Idas modiolaeformis, from seeps of the Nile Deep Sea Fan or the Anaximander mountains mud volcanoes show a wider symbiont diversity, as for thiotrophic phylotypes, and methanotropics or methylotrophic types (Olu-Le Roy et al., 2004; Duperron et al., 2006; Laming et al., 2015). The Bathymodiolinae mussels sampled in the Central Basin and along the northwestern part of the Tekirdağ Basin, thought to be Idas-like sp. nov were later identified as Idas simpsoni already sampled from other zones, from west Ireland to the Mediterranean Sea, based on 
molecular data (Thubaut, 2012). However, as the specimens observed at different locations (Plate I-F and G) during the Marsite cruise were not sampled, we cannot exclude that they may be either Idas modiolaeformis, identified from other eastern Mediterranean cold seep settings from the Mediterranean Ridge to the Nile Deep Sea Fan (Olu-Le Roy et al., 2004; Ritt et al., 2011). Bathymodiolinae mussels Idas modiolaeformis harbor different symbiont types and use either sulfide or methane as energy sources. The two factors limiting Bathymodiolinae mussel settlement are the concentration of methane and the nature of substratum (e.g., Olu-Le Roy et al., 2007; Ritt et al., 2010). Our study shows that Idas-like mussels are present only in the western part of the SoM, in Tekirdağ Basin and possibly on the Western High. Ritt et al., (2012b) has described them also in the Central Basin. In these areas, this species can settle on carbonate chimneys or pavements, or other hard substrata (like the Keşan Turbidite Formation). They have been observed where oil escapes (Tekirdağ NW) and near shimmering fluid (Tekirdağ SE), at the bedding surfaces and near the encountered chimneys. The sampled fluids at all these sites showed high methane content from thermogenic or microbial sources (Ruffine et al., 2018a); (Table I in supplementary material, Figure 7).

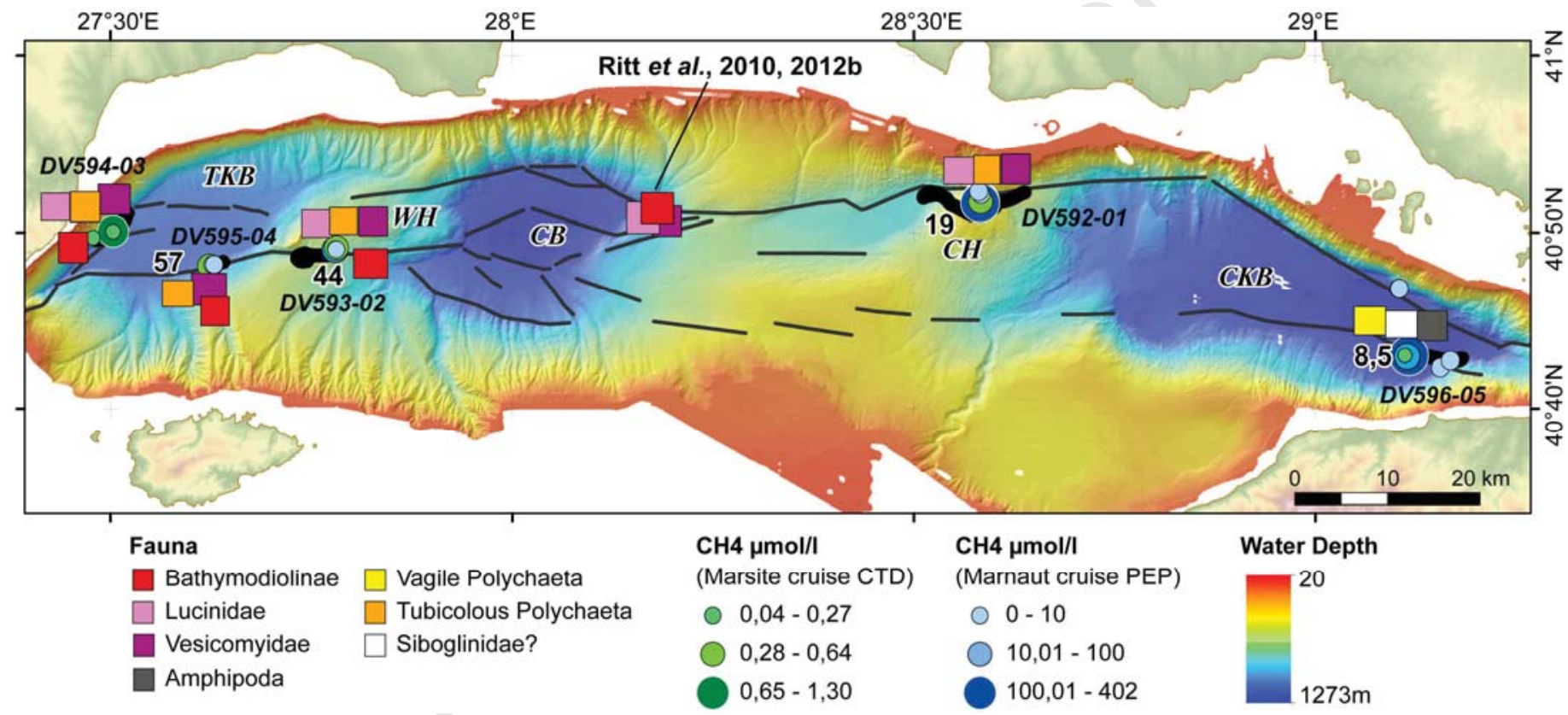

Figure 7: On bathymetric map of the SoM, synthesis of fauna species present. CH4 data are from Marsite cruise CTDRosette (Ruffine et al., 2018b) and Nautile submersible samples from Marnaut cruise (Henry et al., 2007a). The PEP system deployed by the Nautile allows sampling of water not far from the vents in contrast with the CTD rosette deployed form the surface. These two methods explain the difference of $\mathrm{CH}_{4}$ concentrations.

Values in black are oxygen concentrations in $\mu \mathrm{mol} / 1$ (Marnaut cruise, Henry et al., 2007a); TK for Tekirdağ Basin, CK for Çinarcik Basin, WH for Western High and CH for Central High. Note that only empty shells have been observed for Lucinidae.

Fluid flow in the SOM is highly variable from 80 to $34,000 \mathrm{mLn} / \mathrm{min}^{-1}$. Hydrogen sulfide has not been measured in seawater (but is usually under detection limits over the seep sediments), but we may assume that the small mytilids living several centimeters to tens of centimeters below the seafloor, use methane. However, fairly high methane concentrations from 90 to $377 \mu \mathrm{mol} / \mathrm{l}$, measured near the seafloor by the PEP deployed by Nautile (Henry et al., 2007b), have been measured on Central High. No mussels were observed here during the Marsite dive. In Çinarcik 
Basin, high methane concentrations (> $100 \mu \mathrm{mol} / \mathrm{l})$ exist (Henry et al., 2007a; Ruffine et al., 2018b) and no mussels were observed during the dives. Is the concentration too high for their existence? No such measurements were carried out on Tekirdağ Basin, making it difficult to compare. At Regab pockmark offshore West Africa, the methane concentration close to the mussels reached $34 \mu \mathrm{mol} / \mathrm{l}$ (Olu-Le Roy et al., 2007) but at brine pools in the Gulf of Mexico, concentrations as high as $2.75 \mathrm{mmol} / \mathrm{l}(2750 \mu \mathrm{mol} / \mathrm{l})$ have been measured in dense mussel beds (Bergquist et al., 2005). Authigenic crusts are also distributed in the eastern part of the Sea of Marmara, which should allow for mussel colonization. Therefore, both conditions allowing chemosynthesis-based mussel colonization (enough methane level and hard substrata) are present in this eastern part of the Marmara Sea.

The oxygen levels measured at 6 CTD stations during the Marnaut cruise (Henry et al., 2007a) have shown a decreasing gradient along the SoM from west to east (Table I in supplementary material). These results on seawater circulation in this semi-isolated sea, reflect an input of oxygenated water from the Mediterranean Sea by the Dardanelles flowing eastward and an output by the Bosphorus towards the Black Sea, whose deep-sea waters are anoxic (Stanev et al., 2018). The two western stations are well oxygenated (Tekirdağ Basin and Western High), but east of Central High, oxygen concentrations become reduced $(19 \mu \mathrm{M}$ and $8.5 \mu \mathrm{M}$ on the Central High and in the Çinarcik Basin respectively) are below the upper limit of Oxygen Minimum Zones (OMZ) (Figure 7) defined as $0.5 \mathrm{ml}^{-1} \mathrm{I}^{-1}$ (or $20.8 \mu \mathrm{mol} / \mathrm{l}$ ) (Levin, 2003), The bottom waters of the Çinarcik Basin are moreover close to hypoxia conditions which correspond to physiologically stressful oxygen levels which vary among taxa, but defined as $<0.2 \mathrm{ml}$.1 (Kamykowski and Zentara; 1990) and also in the range of dysoxic or dysaerobic waters (0.1 to $\left.1 \mathrm{ml}^{-1^{-1}}\right)$ according to Bernhard \& Sen Gupta (1999) and Levin (2003). While an OMZ is known to occur between 250 and $\sim 450 \mathrm{~m}$ water depths in the SoM (e.g., Beşiktepe et al., 1993), recent measurements confirmed the occurrence of such low oxygen levels in the deep waters of the eastern part of the sea. Ediger et al. (2016) reported a sharp decrease in dissolved oxygen content of bottom waters at $\sim 1200 \mathrm{~m}$ in the Çinarcik Basin from $\sim 2 \mathrm{mg} / \mathrm{L}(62.5 \mu \mathrm{mol} / \mathrm{l})$ in 1995 to $\sim 0.2 \mathrm{mg} / \mathrm{L}(6.25 \mu \mathrm{mol} / \mathrm{l})$ in 2015 (a level below the OMZ in the SoM), and Yucel et al. (2020) "a dramatic recent deoxygenation" in the deep waters $(>900 \mathrm{~m})$ of the SoM with the present concentration $(7.3 \mu \mathrm{mol} / \mathrm{l})$ within the range of those measured during the Marnaut cruise in the Çinarcik Basin $(8.5 \mu \mathrm{mol} / \mathrm{l})$. Both studies attribute this decrease to "possible excessive nutrient fluxes" or "recent increased eutrofication" from the boundaries of the Sea. Oxygen levels close to hypoxia could explain the absence of Bathymodiolinae mussels in the Çinarcik Basin. These small mussels were neither observed in the Central High seep sites, where suboxic oxygen levels were also measured $(19 \mu \mathrm{mol} / 1)$. Among the few data available for dissolved oxygen levels measured in the water surrounding the mussels, the lowest values were found in methane-rich brines of the Gulf of Mexico with $27 \mu \mathrm{mol} / 1$ ( $\left.0.65 \mathrm{ml} . \mathrm{l}^{-1}\right)$ (Bergquist et al., 2005), therefore above both Çinarcik and Central High values and OMZ thresholds.

OMZs represent a major oceanographic boundary for many species. Organic-rich sediments in OMZs support sulphide oxidizing bacterial mats and a high density of small size fauna (protistans and metazoan meiofauna) adapted to hypoxia, but usually show a low density and diversity of macro- and megafauna (Levin, 2003; Yucel et al., 2020). Megafauna is the most affected compared to smaller sized organisms (Gooday et al., 2009), but hypoxia sometimes also leads in single species dominance of macrofauna (Jeffrey et al., 2012). In the Black Sea where sulfidic waters are around below 100-150 m water depth, near the boundary of which meiofauna taxa and small macrofauna taxa are abundant, but there is no megafauna (Sergeeva and Gulin, 2007). Beside bivalves, echinoids could also be limited by 
oxygen levels in the eastern SoM, as they were not observed in the Çinarcik Basin but were fairly abundant elsewhere during dives in the SoM. Indeed, according to the review by Levin (2003), echinoderms, crustaceans and molluscs are much less tolerant to hypoxia than annelids. Some polychaete (spionid, dorvilleid, lumbrinerid and cossurids) families have a capacity to adapt to permanent hypoxia usually through branchial modifications (Lamont and Gage, 2000). No tubiculous worms were observed in the Çinarcik Basin, as opposed to other sites of the SoM. However, there was a high density of vagile polychaetes, which may be dorvilleids, one of the polychaete families most tolerant to hypoxia and sulfide, also supported to their position above the sediment and high motility (Levin et al., 2013; Jumars et al., 2015). Dorvilleids are indeed associated with high organic nitrogen and sulfide levels in the sediments and prominent members of the oxygen minimum-zone (Levin, 2003). Tubiculous Ampeliscid amphipods that occur in OMZs off Oman, Chile, Peru and California, present a high gill surface which is indicative of an adaptation to increase the effectiveness of oxygen uptake (Childress and Siebel, 1998; Levin, 2003). Although they are vagile, the dense amphipods observed in the seepage area of the Çinarcik Basin could present such an adaptation. Another adaptation to oxygen stress is vertical migration as shown for the scavenging amphipod, Orchomene obtusus, exploiting the organic rich but anoxic bottom waters of a fjord and migrating upward into oxygenated waters $100 \mathrm{~m}$ above (De Robertis et al., 2001).

The high density of amphipod is likely related to high organic matter content on the seafloor, or microbial mat development, as motile amphipods are either scavengers, or deposit-feeders. Besides this amphipod family, lucinids are another of the few megafauna taxa that seem particularly widespread and abundant at numerous OMZ sites within the eastern Pacific and the Arabian Sea (Levin, 2003). The presence of sulphide-oxidizing symbionts is also an adaptation in such environments. However, no lucinid shells were observed during the dive on the Çinarcik Basin. Vesicomyids are another exception of symbiont-bearing megafauna occurring at seeps within OMZs (Barry et al., 1997; Sahling et al., 2002; Levin et al., 2010). However, no vesicomyids were found in the Çinarcik Basin, but were present in other seep sites of the western SoM (including the Central high) where the oxygen levels are comprised, from Tekirdağ Basin to Western High, between 57 to $44 \mu \mathrm{mol} / \mathrm{l}$. Nevertheless, the record of several well preserved vesicomyid shells in tubecores taken at a microbial mat of a bubbling site (Teichert et al., 2018) testify to the occurrence of these bivalves in the past. According to a recent communication (Ediger et al., 2016; Yucel et al., 2020), oxygen concentrations have decreased by one order of magnitude over the last 20 years, which may have affected fauna composition, limiting colonization of symbiotic bivalves and even vesicomyids adapted to living at low oxygen concentrations.

A specific observation during the Marsite cruise dives lies in the oil seepages only described on two visited areas: the mud volcanoes of Western High and the NW border of Tekirdağ Basin. On the Western High, the oil seepage coexists with thermogenic gas hydrates characterized by a yellowish color. Previous geochemical analyses showed that the hydrates contain more than $20 \%$-mol of non-methane hydrocarbon, with the highest propane concentration ever measured from natural settings (Bourry et al., 2009). This indicates that both oil and gas phases flow throughout the hydrate deposit. Hydrates were not recovered at the NW border of Tekirdağ Basin, and two gas seeps were sampled at the border of the oil seepage area. These seeps emitted dry gases with more than $99 \%$-mol of methane. However the geochemical analyses revealed that ethane, propane and butane have extremely enriched in ${ }^{13} \mathrm{C}$ indicating a high level of oil degradation, whereas the carbon dioxide is very depleted in ${ }^{13} \mathrm{C}$, thus showing no evidence of secondary methanogenesis (Ruffine et al., 2018a). Oil degradation produces $\mathrm{CO}_{2}$, which is dissolved in the former, enhancing oil 
flow throughout the sediment by reducing its viscosity (Brooks et al., 1989; MacDonald et al., 1989; Sahling et al., 2016). Therefore, the oil is allowed to migrate towards the seafloor more easily, where it forms whips and filaments rising into the water column. The lack of visible oil puddles at the seafloor indicates a low to moderate seepage where most of the oil is transferred and dispersed in the water column.

In the Gulf of Mexico, two species of Bathymodiolinae mussels were closely associated with oil drops and solidified asphalt, including one inhabiting oil-soaked sediments associated with bacterial symbionts supposed to degrade heavy hydrocarbons (Raggi et al., 2013). Vesicomyids were observed in "transition zones" close to hydrate outcrops (Sahling et al., 2016) but only empty shells of vesicomyids were observed in the Campeche Knolls (solidified) asphalt field (MacDonald et al., 2004). Bergquist et al., (2005) also described mussel bed communities at Bush Hill and Green canyon oily sites, with active methane bubbling commonly observed in mussel beds and much of the oil-stained sediment. In the SoM, oil emissions are only focused in the northwestern studied part of the Tekirdağ Basin and on Western High. They do not appear to limit the colonization of the main seep fauna community encountered in the area: Bathymodiolinae, dense Vesicomyidae and tubiculous Polychatea were all observed near and among oil seepages.

Finally, no specific fauna was observed near the $\mathrm{CO}_{2}$ escapes on the NW edge of Tekirdağ basin even if tubiculous polychaetes were observed at the $\mathrm{CO}_{2}-\mathrm{B}$ site on a few focused reduced black patches, probably linked to methane emissions.

It is worth noting that although the long tubeworms seen in the Çinarcik basin near seepages which may be symbiontbearing Siboglinidae tubeworms, also named pogonophorans or vestimentiferans, they have never been sampled in the SoM even if they colonize cold seeps in the Eastern Mediterranean from the South of Crete and Turkey (Olu-Le Roy et al., 2004) and from the Nile Deep Sea Fan (Ritt et al., 2011) with the species Lamellibrachia anaximandri (Southward et al., 2011).

To summarize, the nature and composition of the fluid escapes (oil versus methane) may not be a predominant factor for symbiotic-fauna composition at the scale of the SoM. However further studies would be necessary to explore the diversity of seep associated fauna at the genus and species levels. Indeed, different species of Bathymodiolinae (eg. Idas modioliformis versus I. simpsoni having different symbionts: Laming et al., 2015) or Vesicomyidae (different adaptations regarding sulfide and oxygen levels: Decker et al., 2017) may have different requirements and therefore differ in their distribution regarding fluid composition or fluid flow regimes, influencing their distribution on a smaller scale, as shown by Ritt et al., (2010) in the Çinarcik Basin. Moreover, sediment sampling by cores should enhance our knowledge of infaunal bivalve distribution, such as lucinids. Considering the interaction of seepage of different composition (brackish water, oil, methane, carbon dioxide) and an oxygen gradient from west to east leading to oxygen depletion in the eastern part which seems to limit the colonization of the symbiont-bearing bivalve families, the SoM is an interesting area to study the factors influencing fauna distribution in comparison to the oceanic OMZ other cold-seeps sites (e.g., Pakistan margin, NE Pacific margins off Oregon and California). Interestingly, the heterogeneity of the habitat created by the seeps in the NE Pacific appeared as the main structuring factor of macrofaunal communities, enhancing margin biodiversity and this phenomenon was not lessened by the OMZ (Levin et al., 2010). 
The recent in situ exploration of the SoM during the Marsite cruise ROV dives has revealed diverse manifestations of fluid expulsion on the sea bottom: dark reduced sediment patches, bacterial mats, diverse types of carbonate crusts, active or inactive carbonate chimneys, chemosynthetic and typical benthic fauna. $\mathrm{Gas}\left(\mathrm{CO}_{2}, \mathrm{CH}_{4}\right.$, and heavy hydrocarbons), oil and water (brine, marine, fresh) escape from the seafloor with continuous or discontinuous flows of various strengths.

The localization and type of seeps on the sea bottom are linked to tectonic structures, namely the MMF and the related fault system, the intersection of structures, and sedimentary features which also drive expulsions through stratigraphic discontinuities, erosional unconformities, mass wasting and canyons.

Numerous significant escape sites discovered during previous cruises are still active 7 to 12 years later. The emission of crude oil, a striking feature of the SoM, is confined to the western part of the sea.

Observed fauna include several symbiont-bearing bivalve families such as Bathymodiolinae and Vesicomyidae, as well as Lucinidae empty shells. Tubiculous polychaetes colonise bacterial mats and black, likely sulfidic, sediments, while vagile polychaetes and dense aggregations of amphipods were the only megafauna species observed in the Çinarcik Basin of the SoM, affected by oxygen conditions close to hypoxia. Sea urchins, which are very abundant around seeps and in background sediments in the whole area, seem absent in the Çinarcik Basin.

Our study, which has combined results on the morphology of seep fluids and faunal characteristics, highlights the wide diversity of the explored zones in the Sea of Marmara, at the scale of the whole sea. This diversity also exists at a lesser extent such at the scale of the NW Tekirdağ border or at the scale of the south edge of the Çinarcik basin. Further studies, especially promoting faunal and bacterial sampling, would be necessary to better characterize the diversity of seep communities to decipher the real influence of seep heterogeneity on fauna at genus or species levels, especially in relation to the unusual fluid chemistry variability.

\section{Supplementary data}

These video data consist of 06:11 minutes of near-bottom sequences recorded by the ROV Victor during the Marsite cruise in 2014 (https://doi.org/10.17600/14000500). It shows the diversity of seeps encountered where the sections of video were chosen to illustrate the legend of the seepages (Figure 2B). They are extracted from the five dives carried out on four areas of the SoM: Central and Western highs, Tekirdağ and Çinarcik basins.

The Table I summarizes the geological, geochemical and faunal characteristics of the seeps observed during the Marsite cruise.

\section{Acknowledgements}

This work would not have been possible without the assistance of the crew of the RV Pourquoi pas? and the ROV Victor team. Many thanks to all the participants of the Marsite cruise (https://doi.org/10.17600/14000500) and to 
those involved in the project. A special thanks to Alison Chalm for revising the English. We would like to thank the two anonymous reviewers who contributed, by the relevance of their remarks, to improve this article. Financial support was provided by the European programme «MARsite», under the call ENV.2012.6.4-2: "Long-term monitoring experiment in geologically active regions of Europe proneto natural hazards: the Supersite concept". This work was also supported by the "Laboratoire d'Excellence" LabexMER (ANR-10-LABX-19) through the projects MicroGaMa and MISS Marmara, co-funded by a grant from the French government under the program "Investissements d'Avenir".

\section{Author contributions}

HO, LR, ASA, CS, were involved in the research cruise Marsite (2014).

LR was the chief scientist of the cruise. He was involved in the results of the origin and nature of gases.

$\mathrm{KO}$ worked on the biology data and studied the videos to determine the visible taxa.

HO determined the location and nature of the seepages by viewing the videos. As the first author, she coordinated the paper.

SD has worked extensively on the area and the data of numerous previous cruises. She has helped organize the manuscript and has participated actively in all scientific discussions.

CS carried out the mapping of water column anomalies during the Marsite cruise and the data processing afterwards, with Globe software (CIfremer).

CG worked during his masters on the NW Tekirdağ video data to establish the first map of seeps in this area.

ASA and CG performed the mosaic on BBC site with Matisse software (CIfremer) and all the enhancements of figures using Adobe software. ASA also helped to correlate data.

All authors discussed the results and commented on the manuscript.

\section{Competing interests}

The authors declare no competing interests.

\section{References}

Akhoudas, C., Chevalier, N., Blanc-Valleron, M.M., Klein, V., Mendez-Millan, M., Demange, J., Dalliah, S., Rommevaux, V., Boudouma, O., Pierre, C., Ruffine, L., 2018. Methane-derived stromatolitic carbonate crust from an active fluid seepage in the western basin of the Sea of Marmara: Mineralogical, isotopic and molecular geochemical characterization. Deep-Sea Research Part II 153, 110-120.

Ambraseys, N.N., Jackson, J.A., 2000. Seismicity of the Sea of Marmara (Turkey) since 1500. Geophysical Journal International 141, F1-F6.

Ambraseys, N., 2002. The seismic activity of the Marmara Sea region over the last 2000 years. Bulletin of the Seismological Society of America 92, 1-18.

Armijo, R., Meyer, B., Navarro, S., King, G., Barka, A., 2002. Asymmetric slip partitioning in the Sea of Marmara pull-apart: a clue to propagation processes of the North Anatolian Fault?. Terra Nova 14, 80-86.

Armijo, R., Pondard, N., Meyer, B., Uçarkus, G., de Lepinay, B.M., Malavieille, J., Dominguez, S., Gutscher, M.A., Schmidt, S., Beck, C., Çağatay, N., Çakir, Z., Imren, C., Eris, K., Natalin, B., Özalaybey, S., Tolun, L., Lefevre, I., Seeber, L., Gasperini, L., Rangin, C., Emre, O., Sarikavak, K., 2005. Submarine fault scarps in the Sea of Marmara pull-apart (North Anatolian Fault): Implications for seismic hazard in Istanbul. Geochemistry Geophysics Geosystems 6.

Barry, J.P., Kochevar, R.E., Baxter, C.H., 1997. The influence of pore-water chemistry and physiology in the distribution of vesicomyid clams at cold seeps in Monterey Bay: implications for patterns of chemosynthetic community organization. Limnology and Oceanography 42, 318-328. 
Bayon, G., Loncke, L., Dupré, S., Caprais, J.C., Ducassou, E., Duperron, S., Etoubleau, J., Foucher, J.P., Fouquet, Y., Gontharet, S., Henderson, G.M., Huguen, C., Klaucke, I., Mascle, J., Migeon, S., Olu-Le Roy, K., Ondréas, H., Pierre, C., Sibuet, M., Stadnitskaia, A., Woodside, J., 2009. Multi-disciplinary investigation of fluid seepage on an unstable margin: The case of the Central Nile deep sea fan. Marine Geology 261, 92-104.

Bayon, G., Birot, D., Ruffine, L., Caprais, J.C., Ponzevera, E., Bollinger, C., Donval, J.P., Charlou, J.L., Voisset, M., Grimaud, S., 2011. Evidence for intense REE scavenging at cold seeps from the Niger Delta margin. Earth and Planetary Science Letters 312, 443-452.

Beck, C., Mercier de Lépinay, B., Schneider, J-L., Cremer, M., Çağatay, N., Wendenbauma, E., Boutareaud, S., Ménot-Combes, G., Schmidt, S., Olivier, W., Kadir Eris, K., Armijo, R., Meyer, B., Pondard, N., Gutcher MA., Turon, J.-L, Labeyrie, L. Cortijo, E. Gallet, Y., Bouquerel, H., Gorur, N., Gervais, A., Castera, M.-H., Londeix, L. Rességuier A. de, Jaouen, A., and the MARMACORE Cruise Party, 2007. Late Quaternary coseismic sedimentation in the Sea of Marmara's deep basins. Sedimentary Geology, 199, 65-89.

Bergquist, D.C., Fleckenstein, C., Knisel, J., Begley, B., MacDonald, I.R., Fisher, C.R., 2005. Variations in seep mussel bed communities along physical and chemical environmental gradients. Marine Ecology Progress Series 293, 99-108.

Bernhard, J.M. and Sen Gupta, B.K., 1999. Foraminifera of oxygen depleted environments. In Modern Foraminifera, B.K. Sen Gupta (ed.). Dordrecht: Kluwer, 201-216

Beşiktepe Ş., Özsoy, E., Ünlüata, Ü. 1993. Filling of the Marmara Sea by the Dardanelles lower layer inflow. DeepSea Research I 40, (9), 1815-1838.

Bohnhoff, M., Bulut, F., Dresen, G., Malin, P.E., Eken, T., Aktar, M., 2013. An earthquake gap south of Istanbul. Nature Communications 4.

Bourry, C., Chazallon, B., Charlou, J.L., Donval, J.P., Ruffine, L., Henry, P., Géli, L., Çağatay, M.N., Inan, S., Moreau, M., 2009. Free gas and gas hydrates from the Sea of Marmara, Turkey Chemical and structural characterization. Chemical Geology 264, 197-206.

Brooks, J.M., Kennicutt II, M.C., Mac Donald, I.R., Wilkinson, D.L., Guinasso Jr., N.L., Bidigare, R.R., 1989. Gulf of Mexico hydrocarbon seep communities. Part IV. Descriptions of known chemosynthetic communities, 21st Annual Offshore Technology Conference, Houston, Texas, May 1-4, 1989, pp. 663-667.

Brown, K.M., Tryon, M.D., DeShon, H.R., Dorman, L.M., Schwartz, S.Y., 2005. Correlated transient fluid pulsing and seismic tremor in the Costa Rica subduction zone. Earth and Planetary Science Letters 238, 189-203.

Burnard, P., Bourlange, S., Henry, P., Géli, L., Tryon, M.D., Natal'in, B., Şengör, A.M.C., Özeren, M.S., Çağatay, M.N., 2012. Constraints on fluid origins and migration velocities along the Marmara Main Fault (Sea of Marmara, Turkey) using helium isotopes. Earth and Planetary Science Letters 341, 68-78.

Çağatay, M.N., Görür, N., Algan, O., Eastoe, C., Tchapalyga, A., Ongan, D., Kuhn, T., Kuşçu, I., 2000. Late GlacialHolocene palaeoceanography of the Sea of Marmara: timing of connections with the Mediterranean and the Black Seas. Marine Geology 167, 191-206.

Çağatay, M.N., Özcan, M., Güngör, E., 2004. Pore water and sediment geochemistry in the Marmara Sea (Turkey): early diagenesis and diffusive fluxes. Geochemistry: exploration, environment, analysis. Geol. Soc. 4, 213225.

Çağatay, M.N., Wulf, S. Guichard, F. Özmaral, A., Henry, P, Gasperini, L., 2015. Tephra record from the Sea of Marmara for the last $71 \mathrm{ka}$ and its paleoceanographic implications. Marine Geology, 361: 96-110.

Çağatay, M.N., Yildiz, G., Bayon, G., Ruffine, L., Henry, P., 2018. Seafloor authigenic carbonate crusts along the submerged part of the North Anatolian Fault in the Sea of Marmara: Mineralogy, geochemistry, textures and genesis. Deep-Sea Research Part II 153, 92-109.

Çağatay, M.N. and Uçarkuş, G., 2018. Morphotectonics of the Sea of Marmara: Basins and Highs on the North Anatolian Continental Transform Plate Boundary., doi: 10.1016/B978-0-12-812064-4.00016-5.

Chevalier, N., Bouloubassi, I., Birgel, D., Crémière, A., Taphanel, M.H., Pierre, C., 2011. Authigenic carbonates at cold seeps in the Marmara Sea (Turkey): A lipid biomarker and stable carbon and oxygen isotope investigation. Marine Geology 288, 112-121.

Chevalier, N., Bouloubassi, I., Birgel, D., Taphanel, M.H., Lopez-Garcia, P., 2013. Microbial methane turnover at Marmara Sea cold seeps: a combined 16S rRNA and lipid biomarker investigation. Geobiology 11, 55-71.

Childress, J.J., Seibel, B.A., 1998. Life at stable low oxygen levels: Adaptations of animals to oceanic oxygen minimum layers. Journal of Experimental Biology 201, 1223-1232.

Cosel, R. von, Salas, C., 2001. Vesicomyidae (Mollusca: Bivalvia) of the genera Vesicomya, Waisiuconcha, Isorropodon and Callogonia in the eastern Atlantic and the Mediterranean. Sarsia 86, 333-366.

Crémière, A., Pierre, C., Blanc-Valleron, M.M., Zitter, T., Cağatay, M.N., Henry, P., 2012. Methane-derived authigenic carbonates along the North Anatolian fault system in the Sea of Marmara (Turkey). Deep-Sea Research Part I 66, 114-130. 
Decker, C., Zorn, N., Le Bruchec, J., Caprais, J.C., Potier, N., Leize-Wagner, E., Lallier, F.H., Olu, K., Andersen, A.C., 2017. Can the hemoglobin characteristics of vesicomyid clam species influence their distribution in deep-sea sulfide-rich sediments? A case study in the Angola Basin. Deep Sea Research Part II 142, 219-232.

Dennielou, B., Droz, L., Babonneau, N., Jacq, C., Bonnel, C., Picot, M., Le Saout, M., Saout, Y., Bez, M., Savoye, B., Olu, K., Rabouille, C., 2017. Morphology, structure, composition and build-up processes of the active channel-mouth lobe complex of the Congo deep-sea fan with inputs from remotely operated underwater vehicle (ROV) multibeam and video surveys. Deep-Sea Research Part II 142, 25-49.

De Robertis, A., Eiane, M.K., Rau, G., 2001. Eat and run: anoxic feeding and subsequent aerobic recovery by Orchomene obtusus in Saanich Inlet, British Columbia, Canada. Marine Ecology Progress Series 219, 221227.

Duperron, S., Bergin, C., Zielinski, F., Blazejak, A., Pernthaler, A., McKiness, Z.P., DeChaine, E., Cavanaugh, C.M., Dubilier, N., 2006. A dual symbiosis shared by two mussel species, Bathymodiolus azoricus and Bathymodiolus puteoserpentis (Bivalvia: Mytilidae), from hydrothermal vents along the northern MidAtlantic Ridge. Environmental Microbiology 8, 1441-1447.

Dupré, S., Woodside, J., Foucher, J.P., de Lange, G., Mascle, J., Boetius, A., Mastalerz, V., Stadnitskaia, A., Ondréas, H., Huguen, C., Harmegnies, F.O., Gontharet, S., Loncke, L., Deville, E., Niemann, H., Omoregie, E., Roy, K.O.L., Fiala-Medioni, A., Dahlmann, A., Caprais, J.C., Prinzhofer, A., Sibuet, M., Pierre, C., Damste, J.S.S., Party, N.S., 2007. Seafloor geological studies above active gas chimneys off Egypt (Central Nil Deep Sea Fan). Deep-Sea Research Part I 54, 1146-1172.

Dupré, S., Mascle, J., Foucher, J.P., Harmegnies, F., Woodside, J., Pierre, C., 2014. Warm brine lakes in craters of active mud volcanoes, Menes caldera off NW Egypt: evidence for deep-rooted thermogenic processes. GeoMarine Letters 34, 153-168.

Dupré, S., Scalabrin, C., Grall, C., Augustin, J.M., Henry, P., Şengör, A.M.C., Görür, N., Çağatay, M.N., Géli, L., 2015. Tectonic and sedimentary controls on widespread gas emissions in the Sea of Marmara: Results from systematic, shipborne multibeam echo sounder water column imaging. Journal of Geophysical Research 120, 2891-2912.

Ediger, D., Beken, Ç., Yüksek, Tuğrul, S., 2016. Eutrophication in the Sea of Marmara. In Özsoy et al., (Eds.) The Sea of Marmara; Marine Biodiversity, Fisheries, Conservation and Governance. Turkish Marine Research Foundation (TUDAV), Publication No: 42, Istanbul, TURKEY.pp.723-735.

Eichhubl, P., Greene, H.G., Naehr, T., Maher, N., 2000. Structural control of fluid flow: offshore fluid seepage in the Santa Barbara Basin, California. Journal of Geochemical Exploration 69, 545-549.

Ergintav, S., Reilinger, R.E., Çakmak, R., Floyd, M., Çakir, Z., Doğan, U., King, R.W., McClusky, S., Özener, H., 2014. Istanbul's earthquake hot spots: Geodetic constraints on strain accumulation along faults in the Marmara seismic gap. Geophysical Research Letters 41, 5783-5788.

Escartin, J., Leclerc, F., Olive, J.A., Mevel, C., Cannat, M., Petersen, S., Augustin, N., Feuillet, N., Deplus, C., Bezos, A., Bonnemains, D., Chavagnac, V., Choi, Y.J., Godard, M., Haaga, K.A., Hamelin, C., Ildefonse, B., Jamieson, J.W., John, B.E., Leleu, T., MacLeod, C.J., Massot-Campos, M., Nomikou, P., Paquet, M., Rommevaux-Jestin, C., Rothenbeck, M., Steinfuhrer, A., Tominaga, M., Triebe, L., Campos, R., Gracias, N., Garcia, R., Andreani, M., Vilaseca, G., 2016. First direct observation of coseismic slip and seafloor rupture along a submarine normal fault and implications for fault slip history. Earth and Planetary Science Letters 450, 96-107.

Field, M.E., Jennings, A.E., 1987. Sea-floor gas seeps triggered by a northern California earthquake. Marine Geology 77, 39-51.

Fischer, D., Mogollon, J.M., Strasser, M., Pape, T., Bohrmann, G., Fekete, N., Spiess, V., Kasten, S., 2013. Subduction zone earthquake as potential trigger of submarine hydrocarbon seepage. Nature Geoscience 6, 647-651.

Gasperini, L., Polonia, A., Del Bianco, F., Etiope, G., Marinaro, G., Favali, P., Italiano, F., Cağatay, M.N., 2012. Gas seepage and seismogenic structures along the North Anatolian Fault in the eastern Sea of Marmara. Geochemistry Geophysics Geosystems 13.

Géli, L., Henry, P., Zitter, T., Dupré, S., Tryon, M., Çağatay, M.N., de Lepinay, B.M., Le Pichon, X., Şengör, A.M.C., Görür, N., Natalin, B., Uçarkus, G., Özeren, S., Volker, D., Gasperini, L., Burnard, P., Bourlange, S., Marnaut Scientific, P., 2008. Gas emissions and active tectonics within the submerged section of the North Anatolian Fault zone in the Sea of Marmara. Earth and Planetary Science Letters 274, 34-39.

Géli, L., Ruffine, L. and Henry, P., 2014. https://doi.org/10.17600/14000500

Géli, L., Henry, P., Grall, C., Tary, J.B., Lomax, A., Batsi, E., Riboulot, V., Cros, E., Gürbüz, C., Ișik, S.E., Şengör, A.M.C., Le Pichon, X., Ruffine, L., Dupré, S., Thomas, Y., Kalafat, D., Bayrakci, G., Coutellier, Q., Regnier, T., Westbrook, G., Saritas, H., Çifçi, G., Çağatay, M.N., Özeren, M.S., Görür, N., Tryon, M., Bohnhoff, M., Gasperini, L., Klingelhoefer, F., Scalabrin, C., Augustin, J.M., Embriaco, D., Marinaro, G., Frugoni, F., 
Monna, S., Etiope, G., Favali, P., Becel, A., 2018. Gas and seismicity within the Istanbul seismic gap. Scientific Reports 8.

Gooday, A.J., Levin, L.A., da Silva, A.A., Bett, B.J., Cowie, G.L., Dissard, D., Gage, J.D., Hughes, D.J., Jeffreys, R., Lamont, P.A., Larkin, K.E., Murty, S.J., Schumacher, S., Whitcraft, C., Woulds, C., 2009. Faunal responses to oxygen gradients on the Pakistan margin: A comparison of foraminiferans, macrofauna and megafauna. DeepSea Research Part Ii-Topical Studies in Oceanography 56, 488-502.

Görür, N., Elbek, S., 2013. Tectonic events responsible for shaping the Sea of Marmara and its surrounding region. Geodinamica Acta 26, 1-11.

Grall, C., Henry, P., Dupré, S., Géli, L., Scalabrin, C., Zitter, T.A.C., Şengör, A.M.C., Çağatay, M.N., Çifçi, G., 2018a. Upward migration of gas in an active tectonic basin: An example from the sea of Marmara. Deep-Sea Research Part II 153, 17-35.

Grall, C., Dupré, S., Guérin, C., Normand, A., Gaillot, A., Fleury, J., Henry, P., 2018b. Processed AsterX AUV data from the Sea of Marmara: high-resolution bathymetry and seafloor backscatter images, SEANOE dataset, doi:10.17882/55744

Greinert, J., Bohrmann, G., and Suess, E., 2001. Gas hydrate-associated carbonates and methane-venting at Hydrate Ridge: classification, distribution and origin of authigenic lithologies. Geophysical Monograph-American Geophysical Union, 124, 99-114.

Halbach, P., Holzbecher, E., Reichel, T., Moche, R., 2004. Migration of the sulphate methane reaction zone in marine sediments of the Sea of Marmara- can this mechanism be tectonically induced? Chem. Geol. 205, 73-82.

Henry, P., Şengör, A.M., Çağatay, M.N., and Marnaut scientific party, 2007a. Cruise Report, Marnaut Expedition, p. 85. https://archimer.ifremer.fr/doc/00398/50967/

Henry, P., Tryon, M., Bourlange, S., Géli, L., Zitter, T., Bouloubassi, I., Burnard, P., Çağatay, M.N., Chevalier, N., Gasperini, L., Görür, N., Gerigk, C., Leveque, C., Le Pichon, X., Lopez-Garcia, P., Massol, A., Mercier De Lepinay, B., Natalin, B., Özeren, S., Pierre, C., Ritt, B., Şengör, A.M., Uçarkus, G., 2007b. MARNAUT Dive report. https://archimer.ifremer.fr/doc/00398/50962/

Henry, P., Grall, C., Kende, J., Viseur, S., Özeren, M.S., Şengör, A.M.C., Dupré, S., Scalabrin, C., Géli, L., 2018. A statistical approach to relationships between fluid emissions and faults: The Sea of Marmara case. Deep-Sea Research Part II 153, 131-143.

Hinrichs, K.U., Hayes, J.M., Sylva, S.P., Brewer, P.G., DeLong, E.F., 1999. Methane-consuming archaebacteria in marine sediments. Nature 398, 802-805.

Imren, C., Le Pichon, X., Rangin, C., Demirbağ, E., Ecevitoğlu, B., Görür, N., 2001. The North Anatolian Fault within the Sea of Marmara: a new interpretation based on multi-channel seismic and multi-beam bathymetry data. Earth and Planetary Science Letters 186, 143-158.

Italiano, F., Bonfanti, P., Pizzino, L., Quattrocchi, F., 2010. Geochemistry of fluids discharged over the seismic area of the Southern Apennines (Calabria region, Southern Italy): Implications for Fluid-Fault relationships. Applied Geochemistry 25, 540-554.

Jeffreys, R.M., Levin, L.A., Lamont, P.A., Woulds, C., Whitcraft, C.R., Mendoza, G.F., Wolff, G.A., Cowie, G.L., 2012. Living on the edge: single-species dominance at the Pakistan oxygen minimum zone boundary. Marine Ecology Progress Series 470, 79-U388.

Judd, A.G., Hovland, M., 2007. Seabed Fluid Flow. The Impact on Geology, Biology and the Marine Environment, Cambridge.

Jumars, P.A., Dorgan, K.M., Lindsay, S.M., 2015. Diet of Worms Emended: An Update of Polychaete Feeding Guilds. Annual Review of. Marine Science, 7, 497-520.

Kamykowski, D., Zentara, S.J., 1990. Hypoxia in the world ocean as recorded in the historical data set. Deep-Sea Research I 37, 1861-1874.

Kuşçu, I., Okamura, M., Matsuoka, H., Gökaşan, E., Awata, Y., Tur, H., Şimşek, M., Keçer, M., 2005. Seafloor gas seeps and sediment failures triggered by the August 17, 1999 earthquake in the Eastern part of the Gulf of Izmit, Sea of Marmara, NW Turkey. Marine Geology 215, 193-214.

Laigle, M., Becel, A., de Voogd, B., Hirn, A., Taymaz, T., Özalaybey, S., Team, S.L., 2008. A first deep seismic survey in the Sea of Marmara: Deep basins and whole crust architecture and evolution. Earth and Planetary Science Letters 270, 168-179.

Laming, S.R., Szafranski, K.M., Rodrigues, C.F., Gaudron, S.M., Cunha, M.R., Hilário, A., Le Bris, N., Duperron, S., 2015. Fickle or Faithful: The Roles of Host and Environmental Context in Determining Symbiont Composition in Two Bathymodioline Mussels. PLOS ONE 10.

Lamont, P.A., Gage, J.D., 2000. Morphological responses of macrobenthic polychaetes to low oxygen on the Oman continental slope, NW Arabian Sea. Deep-Sea Research Part II 47, 9-24.

Lantéri, N. and Bignon, L., 2007. Device for taking pressurized samples, European Patent WO/2007/128891. 
Law, C.S., Nodder, S.D., Mountjoy, J.J., Marriner, A., Orpin, A., Pilditch, C.A., Franz, P., Thompson, K., 2010. Geological, hydrodynamic and biogeochemical variability of a New Zealand deep-water methane cold seep during an integrated three-year time-series study. Marine Geology 272, 189-208.

Lazar, C.S., L'Haridon, S., Pignet, P., Toffin, L., 2011. Archaeal Populations in Hypersaline Sediments Underlying Orange Microbial Mats in the Napoli Mud Volcano. Applied and Environmental Microbiology 77, 3120-3131.

Le Pichon, X., Şengör, A.M.C., Demirbağ, E., Rangin, C., Imren, C., Armijo, R., Görür, N., Çağatay, N., de Lepinay, B.M., Meyer, B., Saatçilar, R., Tok, B., 2001. The active Main Marmara Fault. Earth and Planetary Science Letters 192, 595-616.

Leon, R., Somoza, L., Medialdea, T., Gonzalez, F.J., Diaz-del-Rio, V., Fernandez-Puga, M.C., Maestro, A., Mata, M.P., 2007. Sea-floor features related to hydrocarbon seeps in deepwater carbonate-mud mounds of the Gulf of Cadiz: from mud flows to carbonate precipitates. Geo-Marine Letters 27, 237-247.

Levin, L.A., 2003. Oxygen minimum zone benthos: adaptation and community response to hypoxia. Oceanography and Marine Biology: An Annual Review 41, 1-45.

Levin, L.A., Mendoza, G.F., Gonzalez, J.P., Thurber, A.R., Cordes, E.E., 2010. Diversity of bathyal macrofauna on the northeastern Pacific margin: the influence of methane seeps and oxygen minimum zones. Marine Ecology 31, 94-110.

Levin, L.A., Ziebis, W., F. Mendoza, G., Bertics, V.J., Washington, T., Gonzalez, J., Thurber, A.R., Ebbe, B., Lee, R.W., 2013. Ecological release and niche partitioning under stress: Lessons from dorvilleid polychaetes in sulfidic sediments at methane seeps. Deep Sea Research Part II 92, 214-233.

Lichtschlag, A., Cevatoglu, M., Connelly, D.P., James, R.H., Bull, J.M., 2018. Increased Fluid Flow Activity in Shallow Sediments at the $3 \mathrm{~km}$ Long Hugin Fracture in the Central North Sea. Geochemistry Geophysics Geosystems 19, 2-20.

MacDonald, I.R., Boland, G.S., Baker, J.S., Brooks, J.M., Kennicutt, M.C., II, Bidigare, R.R., 1989. Gulf of Mexico hydrocarbon seep communities II. Spatial distribution of seep organisms and hydrocarbons at Bush Hill. Marine Biology 101, 235-247.

MacDonald, I.R., Bohrmann, G., Escobar, E., Abegg, F., Blanchon, P., Blinova, V., Brückmann, W., Drews, M., Eisenhauer, A., Han, X., Hesschen, K., Meier, F., Mortera, C., Naehr, T., Orcutt, B., Bernard, B., Brooks, J., de Farago, M., 2004. Asphalt volcanism and chemosynthetic life in the Campeche Knolls, Gulf of Mexico. Science 304, 999-1002.

Maloney, J.M., Grupe, B.M., Pasulka, A.L., Dawson, K.S., Case, D.H., Frieder, C.A., Levin, L.A., Driscoll, N.W., 2015. Transpressional segment boundaries in strike-slip fault systems offshore southern California: Implications for fluid expulsion and cold seep habitats. Geophysical Research Letters 42, 4080-4088.

Marcon, Y., Ondréas, H., Sahling, H., Bohrmann, G., Olu, K., 2014. Fluid flow regimes and growth of a giant pockmark. Geology 42, 63-66.

Mascle, J., Mary, F., Praeg, D., Brosolo, L., Camera, L., Ceramicola, S., Dupré, S., 2014. Distribution and geological control of mud volcanoes and other fluid/free gas seepage features in theMediterranean Sea and nearby Gulf of Cadiz. Geo-Marine Letters 34, 89-110.

Mau, S., Sahling, H., Rehder, G., Suess, E., Linke, P., Soeding, E., 2006. Estimates of methane output from mud extrusions at the erosive convergent margin off Costa Rica. Marine Geology 225, 129-144.

Mau, S., Rehder, G., Arroyo, I.G., Gossler, J., Suess, E., 2007. Indications of a link between seismotectonics and CH4 release from seeps off Costa Rica. Geochemistry Geophysics Geosystems 8.

Mayer, L.A., Shor, A.N., Clarke, J.H., Piper, D.J.W., 1988. Dense Biological Communities at $3850 \mathrm{~m}$ on the Laurentian Fan and their relationship to the deposits of the 1929 Grand Banks earthquake. Deep-Sea Research Part A 35, 1235-1246.

Meister, P., Liu, B., Ferdelman, T.G., Jorgensen, B.B., Khalili, A., 2013. Control of sulphate and methane distributions in marine sediments by organic matter reactivity (vol 104, pg 183, 2013). Geochimica Et Cosmochimica Acta 113, 225-226.

Michaelis, W., Seifert, R., Nauhaus, K., Treude, T., Thiel, V., Blumenberg, M., Knittel, K., Gieseke, A., Peterknecht, K., Pape, T., Boetius, A., Amann, R., Jorgensen, B.B., Widdel, F., Peckmann, J., Pimenov, N.V., Gulin, M.B., 2002. Microbial reefs in the Black Sea fueled by anaerobic oxidation of methane. Science 297, 1013-1015.

Milkov, A.V., Vogt, P.R., Crane, K., Lein, A.Y., Sassen, R., Cherkashev, G.A., 2004. Geological, geochemical, and microbial processes at the hydrate-bearing Hakon Mosby mud volcano: a review. Chemical Geology 205, 347-366.

Naudts, L., Greinert, J., Artemov, Y., Staelens, P., Poort, J., Van Rensbergen, P., De Batist, M., 2006. Geological and morphological setting of 2778 methane seeps in the Dnepr paleo-delta, northwestern Black Sea. Marine Geology 227, 177-199. 
Niemann, H., Losekann, T., de Beer, D., Elvert, M., Nadalig, T., Knittel, K., Amann, R., Sauter, E.J., Schluter, M., Klages, M., Foucher, J.P., Boetius, A., 2006. Novel microbial communities of the Haakon Mosby mud volcano and their role as a methane sink. Nature 443, 854-858.

Obzhirov, A., Shakirov, R., Salyuk, A., Suess, E., Biebow, N., Salomatin, A., 2004. Relations between methane venting, geological structure and seismo-tectonics in the Okhotsk Sea. Geo-Marine Letters 24, 135-139.

Okay, A.I., Kaşlilar-Özcan, A., Imren, C., Boztepe-Güney, A., Demirbağ, E., Kusşçu, I., 2000. Active faults and evolving strike-slip basins in the Marmara Sea, northwest Turkey: a multichannel seismic reflection study. Tectonophysics 321, 189-218.

Olu, K., Lance, S., Sibuet, M., Henry, P., Fiala Medioni, A., Dinet, A., 1997. Cold seep communities as indicators of fluid expulsion patterns through mud volcanoes seaward of the Barbados accretionary prism. Deep-Sea Research Part I 44, 811-841.

Olu-Le Roy, K., Sibuet, M., Fiala-Médioni, A., Gofas, S., Salas, C., Mariotti, A., Foucher, J.P., Woodside, J., 2004. Cold seep communities in the deep eastern Mediterranean Sea: composition, symbiosis and spatial distribution on mud volcanoes. Deep-Sea Research I 51, 1915-1936.

Olu-Le Roy, K., von Cosel, R., Hourdez, S., Carney, S.L., Jollivet, D., 2007. Amphi-Atlantic cold-seep Bathymodiolus species complexes across the equatorial belt. Deep-Sea Research Part I 54, 1890-1911.

Orange, D.L., Breen, N.A., 1992. The effect of fluids escape on accretionnary wedges.2. Seepage force, slope failure, headless submarine canyons, and vents. Journal of Geophysical Research 97, 9277-9295.

Orange, D.L., Greene, H.G., Reed, D., Martin, J.B., McHugh, C.M., Ryan, W.B.F., Maher, N., Stakes, D., Barry, J., 1999. Widespread fluid expulsion on a translational continental margin: Mud volcanoes, fault zones, headless canyons, and organic-rich substrate in Monterey Bay, California. Geological Society of America Bulletin 111, 992-1009.

Parke, J.R., Minshull, T.A., Anderson, G., White, R.S., McKenzie, D., Kuşçu, I., Bull, J.M., Görür, N., Şengör, C., 1999. Active faults in the Sea of Marmara, western Turkey, imaged by seismic reflection profiles. Terra Nova $11,223-227$.

Pinheiro, L.M., Ivanov, M.K., Sautkin, A., Akhmanov, G., Magalha, V.H., Volkonskaya, A., Monteiro, J.H., Somoza, L., Gardner, J., Hamouni, N., Cunha, M.R., 2003. Mud volcanism in the Gulf of Cadiz: results from the TTR10 cruise. Marine Geology 195, 131-151.

Raggi, L., Schubotz, F., Hinrichs, K.U., Dubilier, N., Petersen, J.M., 2013. Bacterial symbionts of Bathymodiolus mussels and Escarpia tubeworms from Chapopote, an asphalt seep in the southern Gulf of Mexico. Environmental Microbiology 15, 1969-1987.

Rangin, C., E. Demirbag, C. Imren, A. Crusson, A. Normand, E. Le Drezen, and A. Le Bot, 2001. Marine Atlas of the Sea of Marmara (Turkey), Ifremer, Plouzané, France.

Reeburgh, W.S., 1976. Methane Consumption in Cariaco Trench waters and sediments. Earth and Planetary Science Letters 28, 337-344.

Ritger, S., Carson, B., and Suess, E., 1987. Methane-derived authigenic carbonates formed by subduction-induced pore-water expulsion along the Oregon/Washington margin. Geological Society of America Bulletin 98, 147156.

Ritt, B., Sarrazin, J., Caprais, J.C., Noel, P., Gauthier, O., Pierre, C., Henry, P., Desbruyeres, D., 2010. First insights into the structure and environmental setting of cold-seep communities in the Marmara Sea. Deep-Sea Research Part I 57, 1120-1136.

Ritt, B., Pierre, C., Gauthier, O., Wenzhofer, F., Boetius, A., Sarrazin, J., 2011. Diversity and distribution of cold-seep fauna associated with different geological and environmental settings at mud volcanoes and pockmarks of the Nile Deep-Sea Fan. Marine Biology 158, 1187-1210.

Ritt, B., Desbruyeres, D., Caprais, J.C., Gauthier, O., Ruffine, L., Buscail, R., Olu-Le Roy, K., Sarrazin, J., 2012 a. Seep communities from two mud volcanoes in the deep eastern Mediterranean Sea: faunal composition, spatial patterns and environmental control. Marine Ecology Progress Series 466, 93-119.

Ritt, B., Duperron, S., Lorion, J., Lazar, C.S., Sarrazin, J., 2012b. Integrative study of a new cold-seep mussel (Mollusca: Bivalvia) associated with chemosynthetic symbionts in the Marmara Sea. Deep-Sea Research Part I 67, 121-132.

Rubin-Blum, M., Chakkiath, A., Sayavedra, P., Martínez-Pérez, L., Birgel, C., Peckmann, J., Wu, Y.-C., Cárdenas, P., Macdonald, I., Marcon, Y., Sahling, H., Hentschel, U., Dubilier, N., 2019. Fueled by methane: deep-sea sponges from asphalt seeps gain their nutrition from methane-oxidizing symbionts, ISME Journal 13.

Ruffine, L., Fandino Torres, O., Etoubleau, J., Cheron, S., Donval, J.P., Germain, Y., Ponzevera, E., Guyader, V., Dennielou, B., Etiope, G., Gasperini, L., Bortoluzzi, G., Henry, P., Grall, C., Çağatay, M.N., Charlou, J.L., Géli, L., 2012. Geochemical Dynamics of the Natural-Gas Hydrate System in the Sea of Marmara, Offshore Turkey, in: Al-Megren, D.H. (Ed.), Advances in Natural Gas Technology, pp. 29-56. 
Ruffine, L., Germain, Y., Polonia, A., de Prunele, A., Croguennec, C., Donval, J.P., Pitel-Roudaut, M., Ponzevera, E., Caprais, J.C., Brandily, C., Grall, C., Bollinger, C., Géli, L., Gasperini, L., 2015. Pore water geochemistry at two seismogenic areas in the Sea of Marmara. Geochemistry Geophysics Geosystems 16, 2038-2057.

Ruffine, L., Donval, J.P., Croguennec, C., Burnard, P., Lu, H.L., Germain, Y., Legoix, L.N., Bignon, L., Çağatay, M.N., Marty, B., Madre, D., Pitel-Roudaut, M., Henry, P., Géli, L., 2018a. Multiple gas reservoirs are responsible for the gas emissions along the Marmara fault network. Deep-Sea Research Part II 153, 48-60.

Ruffine, L., Ondréas, H., Blanc-Valleron, M.M., Teichert, B.M.A., Scalabrin, C., Rinnert, E., Birot, D., Croguennec, C., Ponzevera, E., Pierre, C., Donval, J.P., Alix, A.S., Germain, Y., Bignon, L., Etoubleau, J., Caprais, J.C., Knoery, J., Lesongeur, F., Thomas, B., Roubi, A., Legoix, L.N., Burnard, P., Chevalier, N., Lu, H.L., Dupré, S., Fontanier, C., Dissard, D., Olgun, N., Yang, H.L., Strauss, H., Özaksoy, V., Perchoc, J., Podeur, C., Tarditi, C., Özbeki, E., Guyader, V., Marty, B., Madre, D., Pitel-Roudaut, M., Grall, C., Embriaco, D., Polonia, M., Gasperini, L., Çağatay, M.N., Henry, P., Géli, L., 2018b. Multidisciplinary investigation on cold seeps with vigorous gas emissions in the Sea of Marmara (MarsiteCruise): Strategy for site detection and sampling and first scientific outcome. Deep-Sea Research Part II 153, 36-47.

Sahling, H., Rickert, D., Lee, R.W., Linke, P., Suess, E., 2002. Macrofaunal community structure and sulfide flux at gas hydrate deposits from the Cascadia convergent margin, NE Pacific. Marine Ecology Progress Series, 231, 121-138.

Sahling, H., Borowski, C., Escobar-Briones, E., Gaytán-Caballero,A., Hsu, C.W., Loher, M., MacDonald, I., Marcon, Y., Pape, T., Römer, M., Rubin-Blum, M., Schubotz, F., Smrzka, D., Wegener, G., Bohrmann, G., 2016. Massive asphalt deposits, oil seepage, and gas venting support abundant chemosynthetic communities at the Campeche Knolls, southern Gulf of Mexico. Biogeosciences, 13, 4491-4512.

Sakic, P., Piete, H., Ballu, V., Royer, J.Y., Kopp, H., Lange, D., Petersen, F., Özeren, M.S., Ergintav, S., Géli, L., Henry, P., Deschamps, A., 2016. No significant steady state surface creep along the North Anatolian Fault offshore Istanbul: Results of 6months of seafloor acoustic ranging. Geophysical Research Letters 43, 68176825.

Salas, C., Woodside, J., 2002. Lucinoma kazani n. sp (Mollusca : Bivalvia): evidence of a living benthic community associated with a cold seep in the Eastern Mediterranean Sea. Deep-Sea Research Part I 49, 991-1005.

Saritas, H., Çifçi, G., Géli, L., Thomas, Y., Marsset, B., Henry, P., Grall, C., Rochat, A., 2018. Gas occurrence and shallow conduit systems in the Western Sea of Marmara: a review and new acoustic evidence. Geo-Marine Letters 38, 385-402.

Schmittbuhl, J., Karabulut, H., Lengline, O., Bouchon, M., 2016. Seismicity distribution and locking depth along the Main Marmara Fault, Turkey. Geochemistry Geophysics Geosystems 17, 954-965.

Sen, A., Ondréas, H., Gaillot, A., Marcon, Y., Augustin, J.M., Olu, K., 2016. The use of multibeam backscatter and bathymetry as a means of identifying faunal assemblages in a deep-sea cold seep. Deep-Sea Research Part I $110,33-49$.

Şengör, A.M., 1979. The North Anatolian transform fault: its age, offset and tectonic significance. Journal of the Geological Society 136, 269-282.

Şengör, A.M.C., Tüysüz, O., Imren, C., Sakinç, M., Eyidoğan, H., Görür, G., Le Pichon, X., Rangin, C., 2005. The North Anatolian Fault: A new look. Annual Review of Earth and Planetary Sciences 33, 37-112.

Şengör, A.M.C., Grall, C., Imren, C., Le Pichon, X., Görür, N., Henry, P., Karabulut, H., Siyako, M., 2014. The geometry of the North Anatolian transform fault in the Sea of Marmara and its temporal evolution: implications for the development of intracontinental transform faults. Canadian Journal of Earth Sciences 51, 222-242.

Sergeeva N.G., Gulin M.B. (2007) Meiobenthos from an active methane seepage area in the NW Black Sea. Marine Ecology, 28, 152-159.

Shillington, D.J., Seeber, L., Sorlien, C.C., Steckler, M.S., Kurt, H., Dondurur, D., Çifçi, G., Imren, C., Cormier, M.H., McHugh, C.M.G., Gürcay, S., Poyraz, D., Okay, S., Atgin, O., Diebold, J.B., 2012. Evidence for widespread creep on the flanks of the Sea of Marmara transform basin from marine geophysical data. Geology 40, 439-442.

Sibuet, M., Olu-Le Roy, K., 2002. Cold Seep Communities on Continental Margins: Structure and Quantitative Distribution Relative to Geological and Fluid Venting Patterns, in: G. Wefer, D. Hebbeln, B.B. Jorgensen, Weering, T.V. (Eds.), Ocean Margin Systems. Springer Verlag, Berlin, pp. 235-251.

Southward, E.C., Andersen, A.C., Hourdez, S., 2011. Lamellibrachia anaximandri n. sp., a new vestimentiferan tubeworm (Annelida) from the Mediterranean, with notes on frenulate tubeworms from the same habitat. Zoosystema 33, 245-279.

Stanev, E.V., Poulain, P.M., Grayek, S., Johnson, K.S., Claustre, H., Murray, J.W., 2018. Understanding the Dynamics of the Oxic-Anoxic Interface in the Black Sea. Geophysical Research Letters 45, 864-871. 
Suess, E., 2014. Marine cold seeps and their manifestations: geological control, biogeochemical criteria and environmental conditions. International Journal of Earth Sciences 103, 1889-1916.

Sun, Q.L., Wu, S.G., Cartwright, J., Dong, D.D., 2012. Shallow gas and focused fluid flow systems in the Pearl River Mouth Basin, northern South China Sea. Marine Geology 315, 1-14.

Talukder, A.R., 2012. Review of submarine cold seep plumbing systems: leakage to seepage and venting. Terra Nova 24, 255-272.

Teichert, B.M.A., Chevalier, N., Gussone, N., Bayon, G., Ponzevera, E., Ruffine, L., Strauss, H., 2018. Sulfatedependent anaerobic oxidation of methane at a highly dynamic bubbling site in the Eastern Sea of Marmara (Çinarcik Basin). Deep-Sea Research Part II 153, 79-91.

Thomas, Y., Marsset, B., Westbrook, G.K., Grall, C., Géli, L., Henry, P., Çifçi, G., Rochat, A., Saritas, H., 2012. Contribution of high-resolution 3D seismic near-seafloor imaging to reservoir-scale studies: application to the active North Anatolian Fault, Sea of Marmara. Near Surface Geophysics 10, 291-301.

Thubaut, J., 2012. Histoire évolutive et biologie des populations des mytilidés associés aux substrats organiques coulés. Approche comparative au sein des Bathymodiolinae des milieux réducteurs profonds., Spécialité : Biologie évolutive. Museum National D'histoire Naturelle, Paris, p. 226.

Tryon, M.D., Henry, P., Çağatay, M.N., Zitter, T.A.C., Géli, L., Gasperini, L., Burnard, P., Bourlange, S., Grall, C., 2010. Pore fluid chemistry of the North Anatolian Fault Zone in the Sea of Marmara: A diversity of sources and processes. Geochemistry Geophysics Geosystems 11.

Vidal, L., Menot, G., Joly, C., Bruneton, H., Rostek, F., Çağatay, M.N., Major, C., Bard, E., 2010. Hydrology in the Sea of Marmara during the last $23 \mathrm{ka}$ : Implications for timing of Black Sea connections and sapropel deposition. Paleoceanography 25.

Yucel, M., Akcay, I., Orek, H., Tezcan, D., Ozkan, K., Ozhan, K., Arkin, S.S, Fach, B., Alimli, N., Sevgen, S., Husrevoglu, S., Mantikci, M., Salihoglu, B., Tugrul, S., 2020. Recent oxygen loss and redox-dependent alteration of seafloor iron, sulfur, nitrogen and phosphorus biogeochemistry in the Sea of Marmara, Ocean Sciences Meeting, 16-21 February 2020, San Diego, California.

Zitter, T.A.C., Henry, P., Aloisi, G., Delaygue, G., Çağatay, M.N., de Lepinay, B.M., Al-Samir, M., Fornacciari, F., Tesmer, M., Pekdeger, A., Wallmann, K., Lericolais, G., 2008. Cold seeps along the main Marmara Fault in the Sea of Marmara (Turkey). Deep-Sea Research Part I 55, 552-570.

Zitter, T.A.C., Grall, C., Henry, P., Özeren, M.S., Çağatay, M.N., Şengör, A.M.C., Gasperini, L., de Lepinay, B.M., Géli, L., 2012. Distribution, morphology and triggers of submarine mass wasting in the Sea of Marmara. Marine Geology 329, 58-74. 


\section{Highlights}

Seeps distribution is strongly related to tectonic and sedimentological features

Settling of fauna seems not connected to nature of fluid escapes

Low levels of seawater oxygen promote the settling of specific fauna species 


\section{Declaration of interests}

$\bigotimes$ The authors declare that they have no known competing financial interests or personal relationships that could have appeared to influence the work reported in this paper.

$\square$ The authors declare the following financial interests/personal relationships which may be considered as potential competing interests: 